\title{
Records of Adult Caligiform Copepods (Crustacea: Copepoda: Siphonostomatoida) in Marine Plankton from East Asia, Including Descriptions of Two New Species of Caligus (Caligidae)
}

\author{
B. A. Venmathi Maran ${ }^{1,2}$, Susumu Ohtsuka ${ }^{2,4}$ and Xu Shang ${ }^{3}$ \\ ${ }^{1}$ Marine Ecosystem Research Division, Korea Institute of Ocean Science \& Technology, \\ Ansan P.O. Box 29, Seoul 425-600, Korea \\ E-mail:bavmaran@gmail.com \\ ${ }^{2}$ Takehara Marine Science Station, Setouchi Field Science Centre, Graduate School of Biosphere Science, \\ Hiroshima University, 5-8-1 Minato-machi, Takehara, Hiroshima 725-0024, Japan \\ E-mail: ohtsuka@hiroshima-u.ac.jp \\ ${ }^{3}$ Wenzhou Medical College, Gao Jiao Yuan Qu, Chashan, Wenzhou, Zhejiang 325035, China \\ ${ }^{4}$ Corresponding author
}

(Received 27 September 2011; Accepted 9 April 2012)

\begin{abstract}
Adults of caligiform copepods are often found in plankton samples, in addition to the naupliar and copepodid stages. Here, we report on adult parasitic copepods of the families Caligidae and Pandaridae from plankton samples collected in Japanese and Chinese coastal waters. The following previously described species were found in 2008: Caligus calotomi Shiino, 1954; C. orientalis Gusev, 1951; C. undulatus Shen and Li, 1959; Lepeophtheirus semicossyphi Yamaguti, 1939; Metacaligus uruguayensis Thomsen, 1949, and Pandarus satyrus Dana, 1852 in Japanese waters; and C. orientalis and C. rotundigenitalis Yü, 1933 in Chinese waters. The findings of adults of Lepeophtheirus and Metacaligus in plankton samples represent the first such a record for each genus. Two new species of Caligus are also described from plankton taken in Japanese waters in 2008 and 2010. An ovigerous female collected from off Iheya Island, Ryukyu Islands, Okinawa Prefecture is described as Caligus quadrigenitalis sp. nov., and two adult females and a male collected from the Seto Inland Sea and off Hirado Island, Kyushu, western Japan is described as Caligus ogawai sp. nov.
\end{abstract}

Key Words: Caligidae, caligiform, copepod, Pandaridae, plankton, sea lice, coastal plankton, life cycle, ectoparasites, Japan, China.

\section{Introduction}

Caligiform copepods (the Caligidae Burmeister, 1835 and their allies) are commonly known as sea lice, and some species have caused serious impacts on cultured fishes (Ho and Lin 2004a; Rosenberg 2008). The presence of adult caligiform copepods in plankton, previously considered as accidental occurrences has recently been highlighted and reevaluated (Venmathi Maran and Ohtsuka 2008; Venmathi Maran et al. 2012a). Also Hayward et al. (2008) noted the occurrence of only adults of Caligus chiastos Lin and Ho, 2003 on cultured tuna with earlier developmental stages totally absent and later concluded that the adults are likely to swim in the water column to search of their final host (Hayward et al. 2011; Venmathi Maran et al. 2012b). Pelagic adults are thus likely to be common in the life cycle of caligiform copepods and the adaptive benefits of free-living adults detached from their hosts were considered by Venmathi Maran and Ohtsuka (2008).

In the present study, three genera of Caligidae (Caligus Müller, 1785, Lepeophtheirus von Nordmann, 1832, and Metacaligus Thomson, 1949) and a single genus of
Pandaridae Milne Edwards, 1840 (Pandarus Leach, 1816) are reported from plankton samples taken in Japanese and Chinese waters. Adults of Caligus have been reported repeatedly from plankton samples (Heegaard 1972; Pillai 1985; Todd et al. 1996; Suàrez Morales et al. 1998, 2003, 2012; Ho and Lin 2004b; Venmathi Maran and Ohtsuka 2008; Venmathi Maran et al. 2012a), but in contrast, adults of Lepeophtheirus and Metacaligus have never been reported from the plankton until now. Hull et al. (1998) did however, report that Lepeophtheirus is known to switch host individuals in aquaculture facilities, in addition to which the developmental stages of Lepeophtheirus salmonis (Krøyer, 1837) have been reported in plankton samples around aquaculture facilities (Costello et al. 1998; Penston et al. 2004) but not from open oceanic waters. Pandarid males are routinely found in the plankton (Cressey 1967; Kabata 1979; Venmathi Maran and Ohtsuka 2008), and a young male of Pandarus satyrus Dana, 1852 was collected from Japan during the present study.

In this paper, we report on the occurrence of altogether eight caligids and a pandarid newly discovered from plankton samples in East Asia, including two new species. Full descriptions are given for the new species; supplemental 


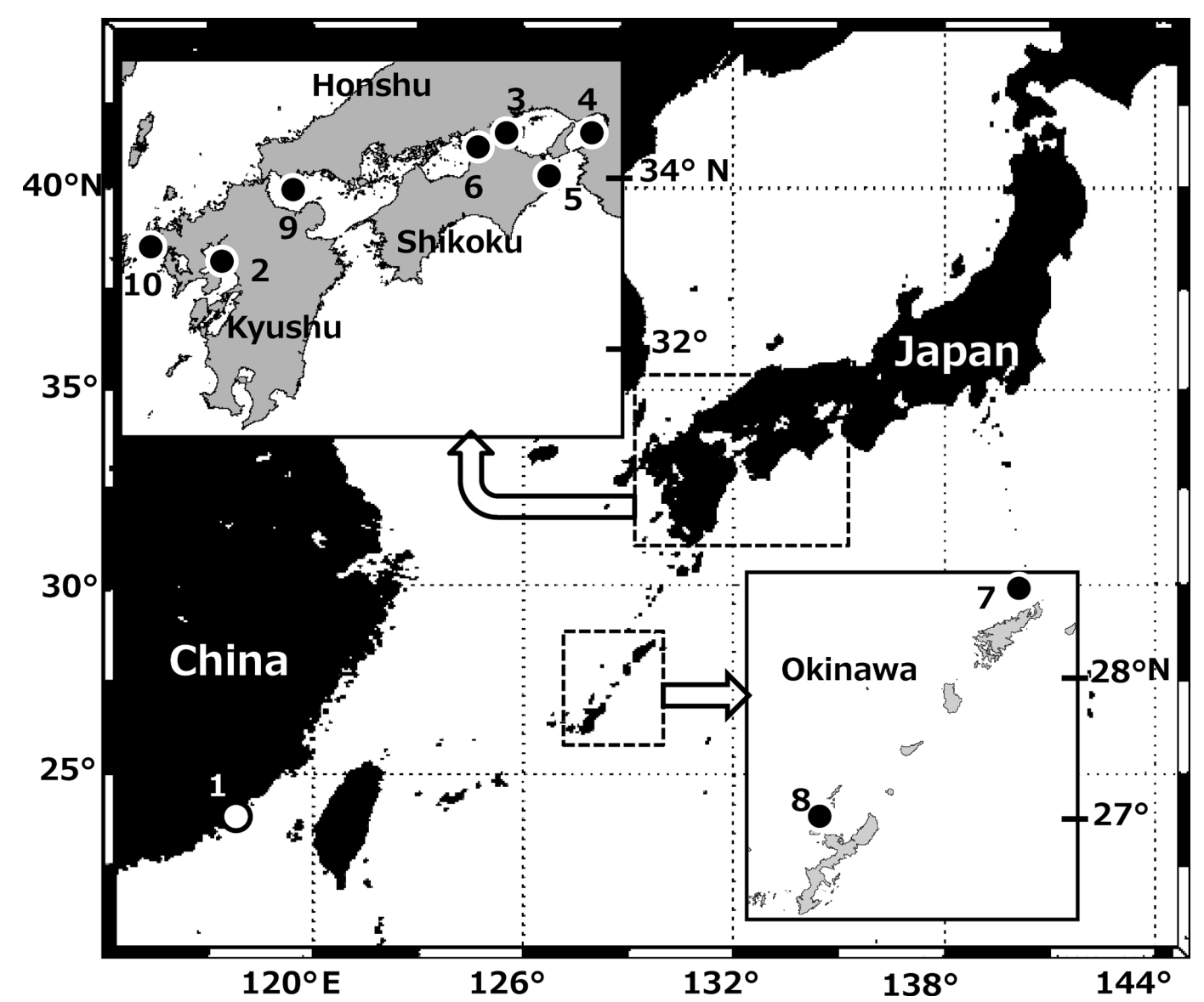

Fig. 1. Collection sites of pelagic caligiform copepods, including one station in China (St. 1 in 2008) and 9 stations in Japan (Sts 2-8 in 2008; Sts 9, 10 in 2010). For details see Table 1.

information is given for the previously described species.

\section{Materials and Methods}

Plankton samples were collected using plankton nets of various design at nine stations in brackish, coastal and oceanic waters of Japan (seven stations in 2008, two in 2010) and one station in Chinese waters in 2008 (Fig. 1, Table 1). The collection from off Akuseki Island, Tokara Islands, Kagoshima Prefecture (St. 7), Japan, was made by surface towing with an ORI net (diameter $1.6 \mathrm{~m}$; mesh size $0.33 \mathrm{~mm}$ ) for $75 \mathrm{~min}$. A sledge net (mesh size $0.3 \mathrm{~mm}$ ) was used in the following localities in Japan: Nagasu off Shodo Island, Seto Inland Sea, Kagawa Prefecture (St. 3); Suo-nada, Seto Inland Sea (St. 9); and off Hirado Island, Nagasaki Prefecture (St. 10). Samples from the other six localities were collected using small plankton nets (diameter 30 or $45 \mathrm{~cm}$; mesh size 0.1 or $0.3 \mathrm{~mm}$ ). At Amoy (=Xiamen), Fujian Province, China (St. 1) and in the Ariake Sea, Saga Prefecture, Japan (St. 2), plankton nets were used alone, but off Osaka, Osaka Prefecture (St. 4), off Tokushima, Tokushima Prefecture (St. 5), off Takamatsu, Kagawa Prefecture (St. 6), and off Iheya Island, Ryukyu Islands, Okinawa Prefecture (St. 8), a fishcollecting light was used together with small plankton nets at night.

Samples were fixed in $10 \%$ neutralized formalin seawater or immediately preserved in $70 \%$ ethanol after collection. Caligiform copepods were sorted from the samples later and transferred to $70 \%$ ethanol. Specimens were cleared in lactophenol for $1-2 \mathrm{~h}$ and observed under a differential interference contrast microscope (Olympus BX50, Tokyo) at magnifications up to $1000 \times$. All drawings were made with the aid of a drawing tube. The morphological terminology follows Huys and Boxshall (1991) and Ho and Lin (2004a). The common and scientific names of the host fish follow Froese and Pauly (2012).

The specimens are deposited at the Kitakyushu Museum of Natural History and Human History, Kitakyushu, Japan (KMNH IvR) and Xiamen University, Xiamen, China (XOB-PC).

\section{Order Siphonostomatoida Thorell, 1859 Family Caligidae Burmeister, 1835 Caligus calotomi Shiino, 1954}

(Fig. 2A)

Caligus calotomi Shiino, 1954a: 16; Yamaguti 1963: 55; Lin and Ho 2007: 51.

Caligus sp.: Venmathi Maran and Ohtsuka 2008: 209; Nagasawa et al. 2010: 103.

Material examined. One adult $\hat{\sigma}$ (KMNH IvR 500,499), Tokushima Port, Tokushima Prefecture, Japan (St. 
Table 1. Adults of Caligus and Pandarus found in plankton samples in East Asia in 2008 and 2010.

\begin{tabular}{|c|c|c|c|c|c|}
\hline Species & No. and Sex & Locality and Station No. & Lat. and Long. & Date & Gear \\
\hline \multicolumn{6}{|l|}{ Caligidae } \\
\hline Caligus orientalis & 19 & Amoy, China (St. 1) & $24^{\circ} 36.0^{\prime} \mathrm{N}, 118^{\circ} 44.0^{\prime} \mathrm{E}$ & 20 Sep 2008 & Small conical net \\
\hline Caligus rotundigenitalis & $1 \widehat{\jmath}$ & Amoy, China (St. 1) & $24^{\circ} 36.0^{\prime} \mathrm{N}, 118^{\circ} 44.0^{\prime} \mathrm{E}$ & 20 Sep 2008 & \\
\hline Caligus orientalis & $1 \delta$ & Ariake Sea, Japan (St. 2) & $33^{\circ} 25.0^{\prime} \mathrm{N}, 129^{\circ} 67.0^{\prime} \mathrm{E}$ & $06 \mathrm{Jul} 2008$ & \\
\hline Caligus undulatus & $2+, 1 \jmath$ & $\begin{array}{l}\text { Takamatsu Port, Japan } \\
\quad \text { (St. 6) }\end{array}$ & $34^{\circ} 14.4^{\prime} \mathrm{N}, 133^{\circ} 26.3^{\prime} \mathrm{E}$ & 03 Oct 2008 & \\
\hline Caligus calotomi & $1 \delta^{\lambda}$ & $\begin{array}{l}\text { Tokushima Port, Japan } \\
\text { (St. 5) }\end{array}$ & $34^{\circ} 03.0^{\prime} \mathrm{N}, 134^{\circ} 36.0^{\prime} \mathrm{E}$ & 04 Oct 2008 & \\
\hline Caligus quadrigenitalis n. sp. & 19 & $\begin{array}{l}\text { off Iheya Island, Japan } \\
\quad \text { (St. 8) }\end{array}$ & $27^{\circ} 00.0^{\prime} \mathrm{N}, 127^{\circ} 55.0^{\prime} \mathrm{E}$ & 22 May 2008 & \\
\hline \multirow[t]{3}{*}{ Caligus ogawai n. sp. } & $2 \uparrow, 1 \AA$ & $\begin{array}{l}\text { Nagasu, off Shodo-Island, } \\
\text { Japan (St. 3) }\end{array}$ & $34^{\circ} 32.3^{\prime} \mathrm{N}, 134^{\circ} 03.7^{\prime} \mathrm{E}$ & 07 Oct 2008 & Sledge net \\
\hline & & $\begin{array}{l}\text { Suo-nada, Seto Inland Sea, } \\
\text { Japan (St. 9) }\end{array}$ & $33^{\circ} 51.5^{\prime} \mathrm{N}, 131^{\circ} 20.0^{\prime} \mathrm{E}$ & 28 Oct 2010 & \\
\hline & & $\begin{array}{l}\text { off Hirado Island, Kyushu, } \\
\text { Japan (St. 10) }\end{array}$ & $33^{\circ} 11.9^{\prime} \mathrm{N}, 129^{\circ} 29.3^{\prime} \mathrm{E}$ & 29 Oct 2010 & \\
\hline Lepeophtheirus semicossyphi & 19 & $\begin{array}{l}\text { off Iheya Island, Japan } \\
\text { (St. 8) }\end{array}$ & $27^{\circ} 00.0^{\prime} \mathrm{N}, 127^{\circ} 55.0^{\prime} \mathrm{E}$ & 22 May 2008 & Small conical net \\
\hline Metacaligus uruguayensis & 19 & Osaka Port, Japan (St. 4) & $34^{\circ} 64.8^{\prime} \mathrm{N}, 135^{\circ} 55.4^{\prime} \mathrm{E}$ & 05 Oct 2008 & \\
\hline \multicolumn{6}{|l|}{ Pandaridae } \\
\hline Pandarus satyrus (young) & $1 \delta^{\lambda}$ & $\begin{array}{l}\text { off Akuseki Island, Japan } \\
\text { (St. 7) }\end{array}$ & $29^{\circ} 16.0^{\prime} \mathrm{N}, 129^{\circ} 52.1^{\prime} \mathrm{E}$ & 27 May 2008 & ORI net \\
\hline
\end{tabular}

Small conical net $=$ diameter $30 \mathrm{~cm}$, mesh size $0.33 \mathrm{~mm}$; Sledge net $=$ mesh size $0.3 \mathrm{~mm}$; ORI Net $=$ diameter $1.6 \mathrm{~m}$, mesh size $0.33 \mathrm{~mm}$.

\section{5), 4 October 2008 (Table 1).}

Description. Male. Body (Fig. 2A) $3.09 \mathrm{~mm}$ long, excluding caudal setae. Cephalothorax suborbicular, longer than wide, $2.25 \times 1.68 \mathrm{~mm}$. Fourth pediger wider than long, $0.21 \times 0.37 \mathrm{~mm}$. Genital complex with triangular posterior corners representing legs 5 and $6,0.50 \times 0.71 \mathrm{~mm}$, ornamented dorsolaterally with conspicuous sensilla. Abdomen small, rectangular, wider than long, $0.14 \times 0.31 \mathrm{~mm}$. Caudal ramus longer than wide, $0.12 \times 0.10 \mathrm{~mm}$, armed with 3 short subterminal and 3 long terminal setae.

Remarks. The present species was originally recorded in plankton from the Nansei Islands, southwestern Japan, as an unidentified species of Caligus (Venmathi Maran and Ohtsuka 2008), but we now refer it to C. calotomi based on the redescription of Lin and Ho (2007). This is the second record of this species from Japan from plankton samples, although males have not so far been reported on any fish host as parasites in Japan (Shiino 1954a; Nagasawa et al. 2010). The present specimen is slightly smaller $(3.09 \mathrm{~mm})$ than the previous one $(3.13 \mathrm{~mm}$, cf. Venmathi Maran and Ohtsuka 2008), $3.16 \mathrm{~mm}$ which itself was similarly shorter than the original specimen from Taiwan (Lin and Ho 2007). A close comparison with the original description shows a minor difference in the shape of the maxillule. According to Lin and Ho (2007), the base of the maxillule nearby the setae is not curved (=straight), but it is curved in our specimens (cf. Venmathi Maran and Ohtsuka 2008).

Distribution. Caligus calotomi was first found as a parasite on the Japanese parrotfish Calotomus japonicus (Valenciennes, 1840) collected from Nagashima, Mie Prefecture and a few additional specimens were found freely swimming in the public aquarium at the Seto Marine Biological Laboratory, Shirahama, Wakayama Prefecture (Shiino 1954a).
These were all females, and the male remained unreported from Japan until we found it in the plankton (Venmathi Maran and Ohtsuka 2008). We recently examined the host fish C. japonicus from Uwajima in Ehime Prefecture, but, none was found with caligids (Venmathi Maran, personal observation). Hence, the present find is the second report of male of this species from Japan following our previous report (Venmathi Maran and Ohtsuka 2008; Nagasawa et al. 2010). Around Taiwan, a female and a male were found on a torpedo scad, Megalaspis cordyla (Linnaeus, 1758), and a striped bonito, Sarda orientalis (Temminck and Schlegel, 1844), respectively (Lin and Ho 2007).

\section{Caligus quadrigenitalis sp. nov.}

(Figs. 2B, 3, 4)

Material examined. Holotype: Ovigerous $q$ (KMNH IvR 500,500), off Iheya Island, Ryukyu Islands, Okinawa Prefecture, Japan (St. 8), 22 May 2008 (Table 1).

Description. Female. Body (Fig. 2B) $3.34 \mathrm{~mm}$ long, excluding caudal setae. Cephalothorax suborbicular, $2.45 \times$ $2.40 \mathrm{~mm}$, frontal plate (Fig. 2C) narrow. Fourth pediger almost entirely covered by cephalothorax, wider than long, $0.28 \times 0.43 \mathrm{~mm}$. Genital complex rectangular, more than twice as wide as long, $0.67 \times 1.43 \mathrm{~mm}$; lateral surface with fine sensilla (Fig. 2D). Abdomen (Fig. 2E) small, rectangular, wider than long, $0.15 \times 0.27 \mathrm{~mm}$, bearing sensilla near caudal region; tone quarter as long as genital complex. Caudal ramus (Fig. 2F) wider than long, $0.09 \times 0.12 \mathrm{~mm}$, with 3 long terminal setae and 3 short subterminal setae. Egg string uniseriate, only present on one side, broken, containing 12 eggs.

Antennule (Fig. 2G) 2-segmented; proximal segment 

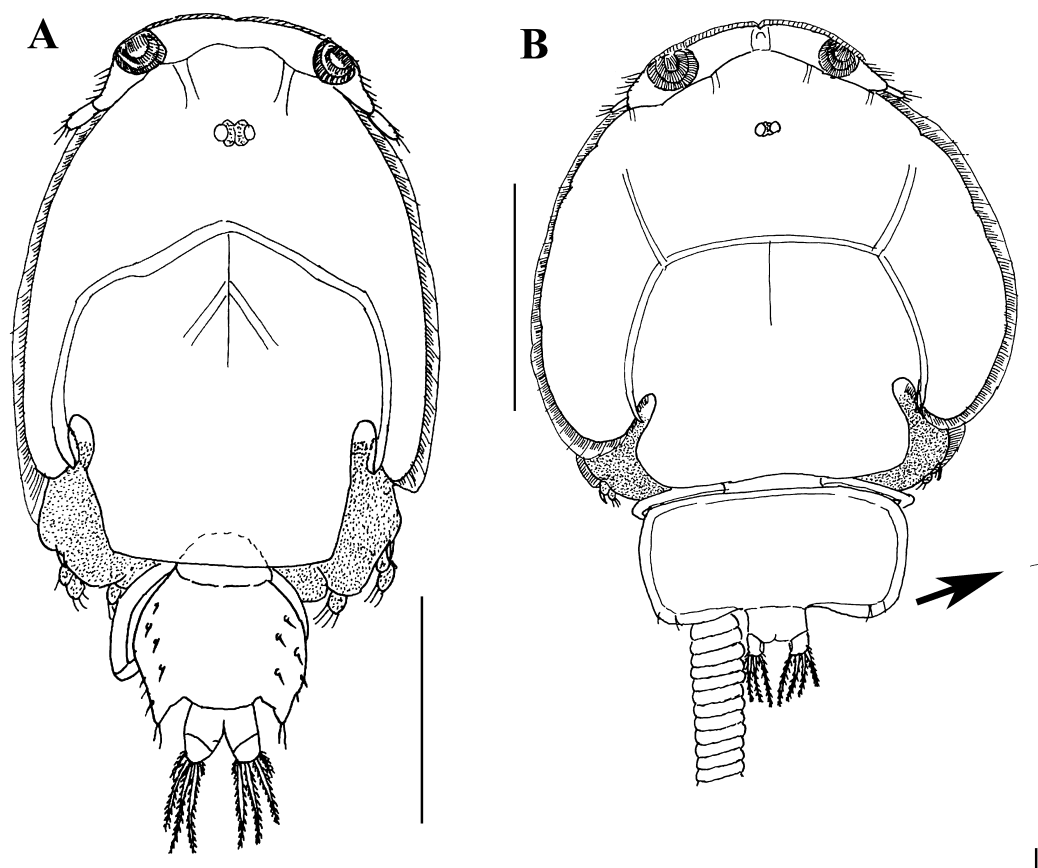

\section{D}

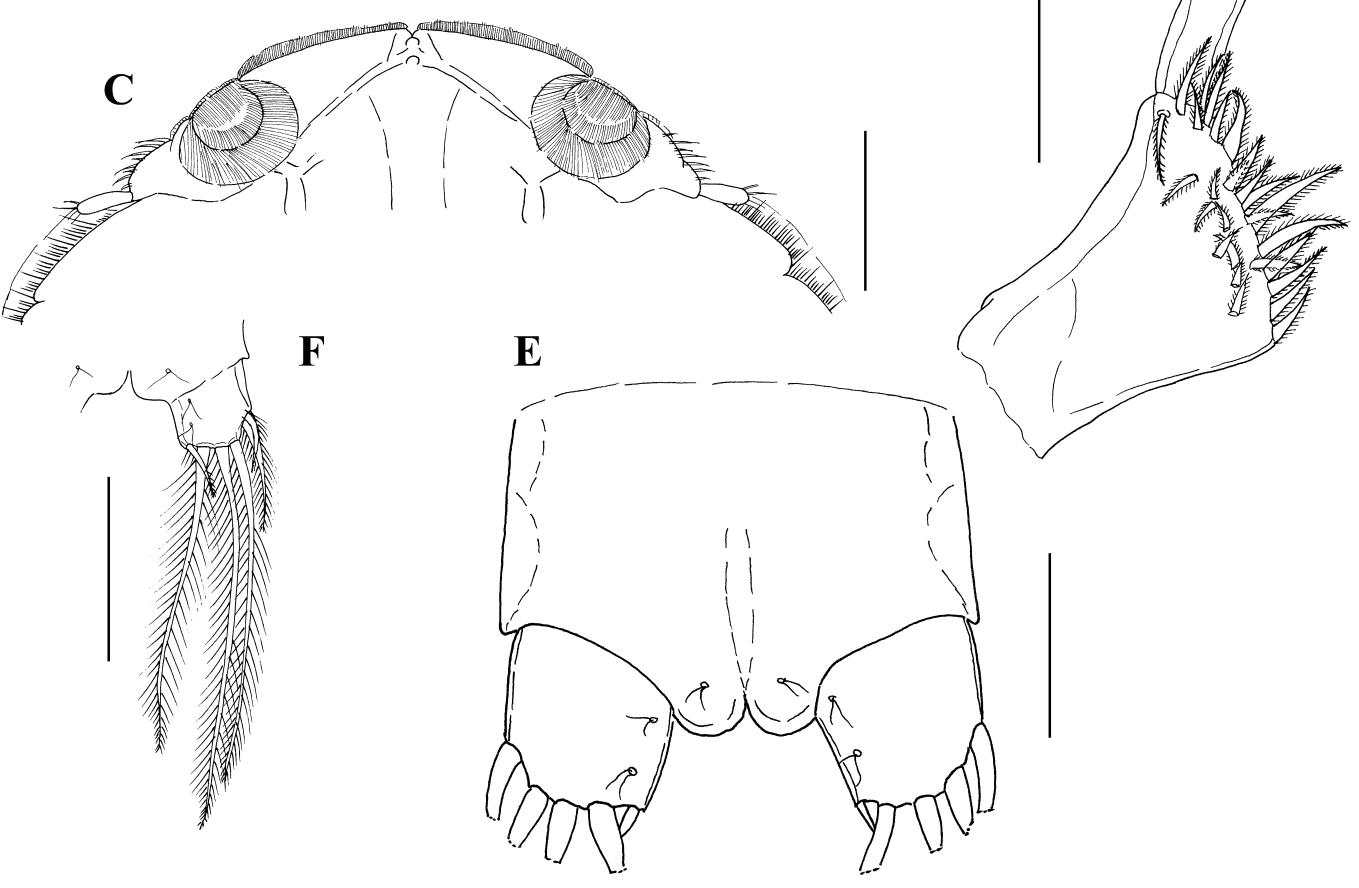

Fig. 2. Two species of Caligus from plankton samples. A, Caligus calotomi Shiino, 1954, male (KMNH IvR 500,409), habitus, dorsal view. B-G, Caligus quadrigenitalis sp. nov., holotype, female (KMNH IvR 500,500): B, habitus; C, frontal plate enlarged; D, lateral region of genital complex showing setules and leg 5; E, abdomen; F, caudal ramus; G, antennule. Scale bars: $1 \mathrm{~mm}$ (A, B), $0.2 \mathrm{~mm}$ (C), $0.1 \mathrm{~mm}$ (D-G).

distinctly longer than distal segment, armed with 27 setae; distal segment armed with subterminal seta on posterior margin and 11 setae plus 2 aesthetascs at tip. Antenna (Fig. 3A) 3-segmented; proximal segment large, with dentiform process on postero-medial surface, without armature elements; middle segment with single seta; distal segment drawn out into recurved claw bearing single seta. Postantennal process (Fig. 2G) weakly curved with membraneous flange, bearing 2 basal papillae, each with long setule; another similar papilla located nearby on sternite. Mandible (Fig. 3B) long, bearing 12 marginal teeth subapically. Maxillule (Fig. 3A) comprising tapering, dentiform posterior process with membraneous flange, and anterior papilla bearing 1 long and 2 short setae. Maxilla (Fig. 3C) 2-segmented, proximal segment large and unarmed; distal segment slender, bearing small, subterminal, hyaline membrane on outer edge, carrying 2 curved elements, each with strips of serrated, hyaline membrane. Maxilliped (Fig. 3D) 3-segmented, proximal segment large and unarmed; middle segment indistinct; basal segment bearing medial seta, claw with seta at base (Fig. 3E). Sternal furca (Fig. 3F) with subquadrate box and bluntly pointed tines with well developed flanges.

Armature on rami of legs 1-4 summarized in Table 2.

Leg 1 (Fig. 4A) protopod consisting of coxa with 2 setules, 

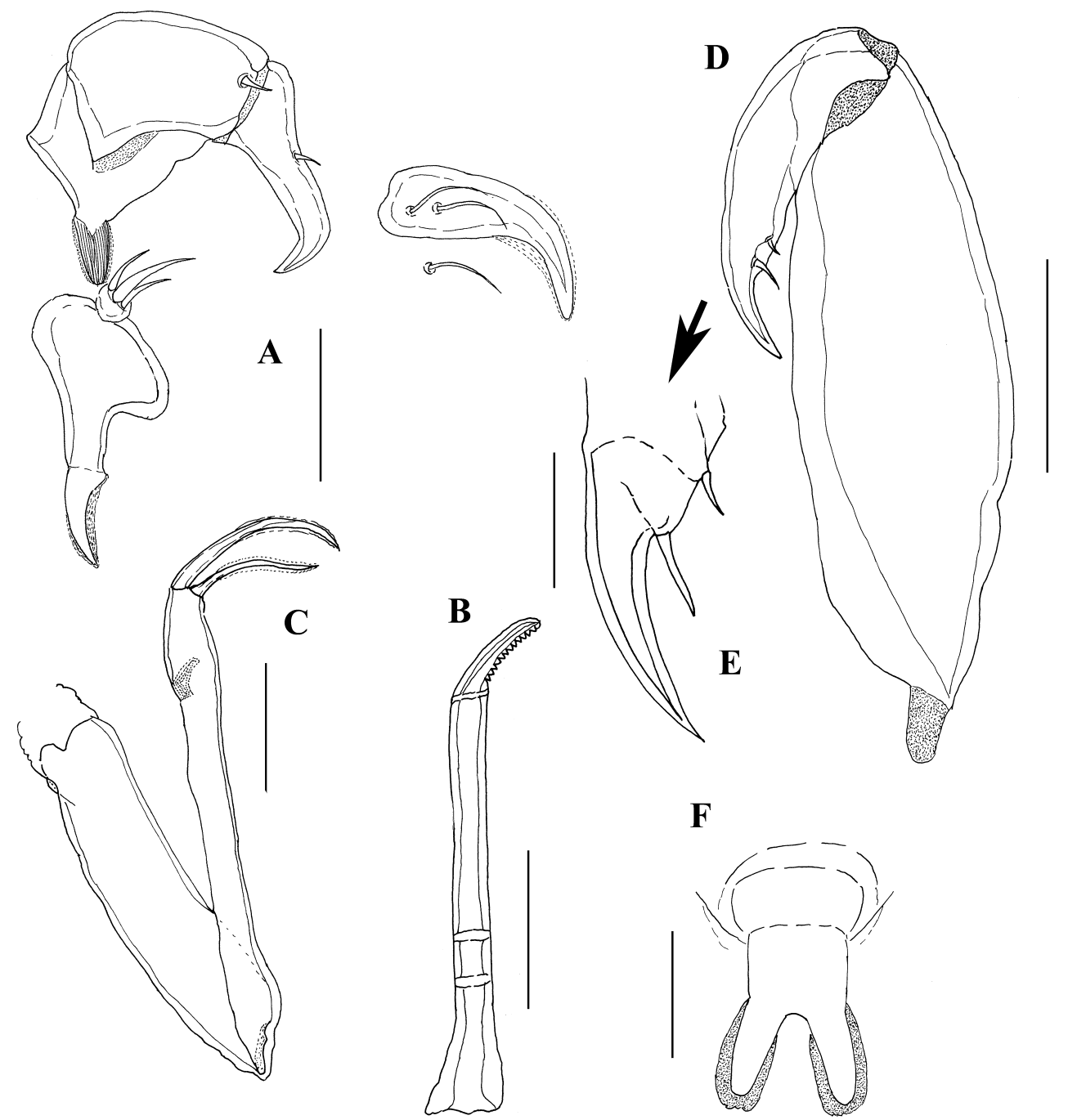

Fig. 3. Caligus quadrigenitalis sp. nov., holotype, female (KMNH IvR 500,500). A, antenna, postantennal process, and maxillule; B, mandible; C, maxilla; D, maxilliped; E, claw enlarged, maxilliped; F, sternal furca. Scale bars: $0.1 \mathrm{~mm}$.

and basis with long, plumose outer seta and short, plumose inner seta; vestigial endopod tipped with setal vestiges; middle 2 of 4 terminal elements on distal margin of second exopodal segment bifid (Fig. 4B). Leg 2 (Fig. 4C) coxa ornamented with setule bearing papilla on anterior surface and large, plumose inner seta on posterodistal corner; basis with small, naked outer seta, bearing setule-bearing papilla on ventral surface; outer and medial margins of basis fringed with membrane; similar membrane on outer margin of proximal segment of exopod. Leg 3 (Fig. 4D) with protopod bearing small outer (basal) plumose seta and large inner (coxal) plumose seta, bearing spinules venterolaterally, free margins of both segments with marginal membranes, and margin with setules bearing papilla. Leg 4 (Fig. $4 \mathrm{E}$ ) with long protopod, bearing outer plumose seta; exopod 2-segmented, first segment with long spine, reaching to midlength of distal segment; pecten present at base of each of 3 distal exopodal spine, these spines increasing in length distally (Fig. 4E). Leg 5 (Fig. 2D) represented by 2 papillae tipped, respectively with 2 and 1 pinnate setae and located on posterolateral margin of genital complex.

Remarks. This new species can be differentiated from its congeners by the following prominent features: (1) the genital complex is rectangular and more than twice as wide as long; (2) the fourth pedigerous somite is almost entirely covered by the posteriorly protruding margin of the cephalothorax; (3) the abdomen is small, only one-fourth the length of the genital complex; (4) the maxilliped has an extra, medial seta terminally; and (5) the exopod of leg 4 is armed with I-0, III long and slender spines.

The extra seta on the maxilliped is also present in C. oviceps Shiino, 1952 and C. pampi Ho and Lin, 2002 (Ho and Lin 2004a), but, both of these differ markedly from C. quadrigenitalis in the sternal furca (curved tines in C. oviceps; tines joined side-by-side in C. pampi; vs bluntly pointed separate tines in the new species).

The new species shares with C. orientalis Gusev, 1951 and C. polycanthi Gnanamuthu, 1950 a similarly small abdomen and a 2-segmented exopod with an armature of I-0; III on leg 4; with C. longispinosus Heegaard, 1962 the posterior margin of the cephalothorax that covers the fourth pedigerous somite and the same sort of leg 4 exopod; and with $C$. oculicola Tang and Newbound, 2004 a similarly small abdomen and again the segment of leg 4 (Tang and Newbound 


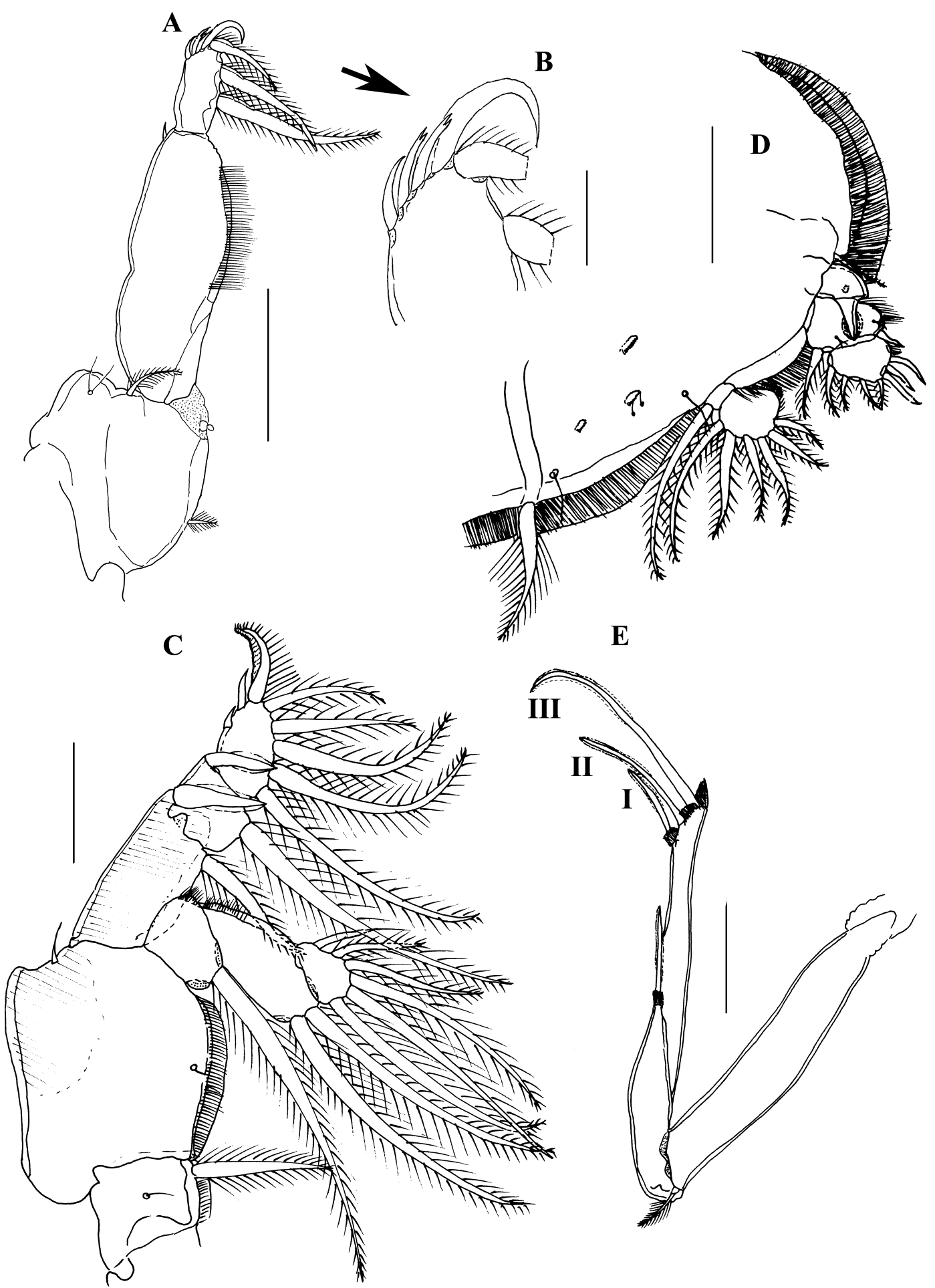

Fig. 4. Caligus quadrigenitalis sp. nov., holotype, female (KMNH IvR 500,500). A, leg 1; B, distal tip of exopod of leg 1 enlarged; C, leg 2; D, leg 3; E, leg 4. Scale bars: $0.1 \mathrm{~mm}$ (A-E), $0.05 \mathrm{~mm}$ (B).

Table 2. Caligus quadrigenitalis sp. nov: armature on rami of legs 1-4 (Roman and Arabic numerals indicate spines and setae, respectively).

\begin{tabular}{ccccc}
\hline & Coxa & Basis & Exopod & Endopod \\
\hline Leg 1 & $0-0$ & $1-1$ & 1-0; III, I, 3 & (vestigial) \\
Leg 2 & $0-1$ & $1-0$ & I-1, I-1, II, I, 5 & $0-1 ; 0-2 ; 6$ \\
Leg 3 & $0-1$ & $1-0$ & I-0; I-1; III, 4 & $0-1 ; 6$ \\
Leg 4 & $0-0$ & $1-0$ & I-0; III & (absent) \\
\hline
\end{tabular}


A

C
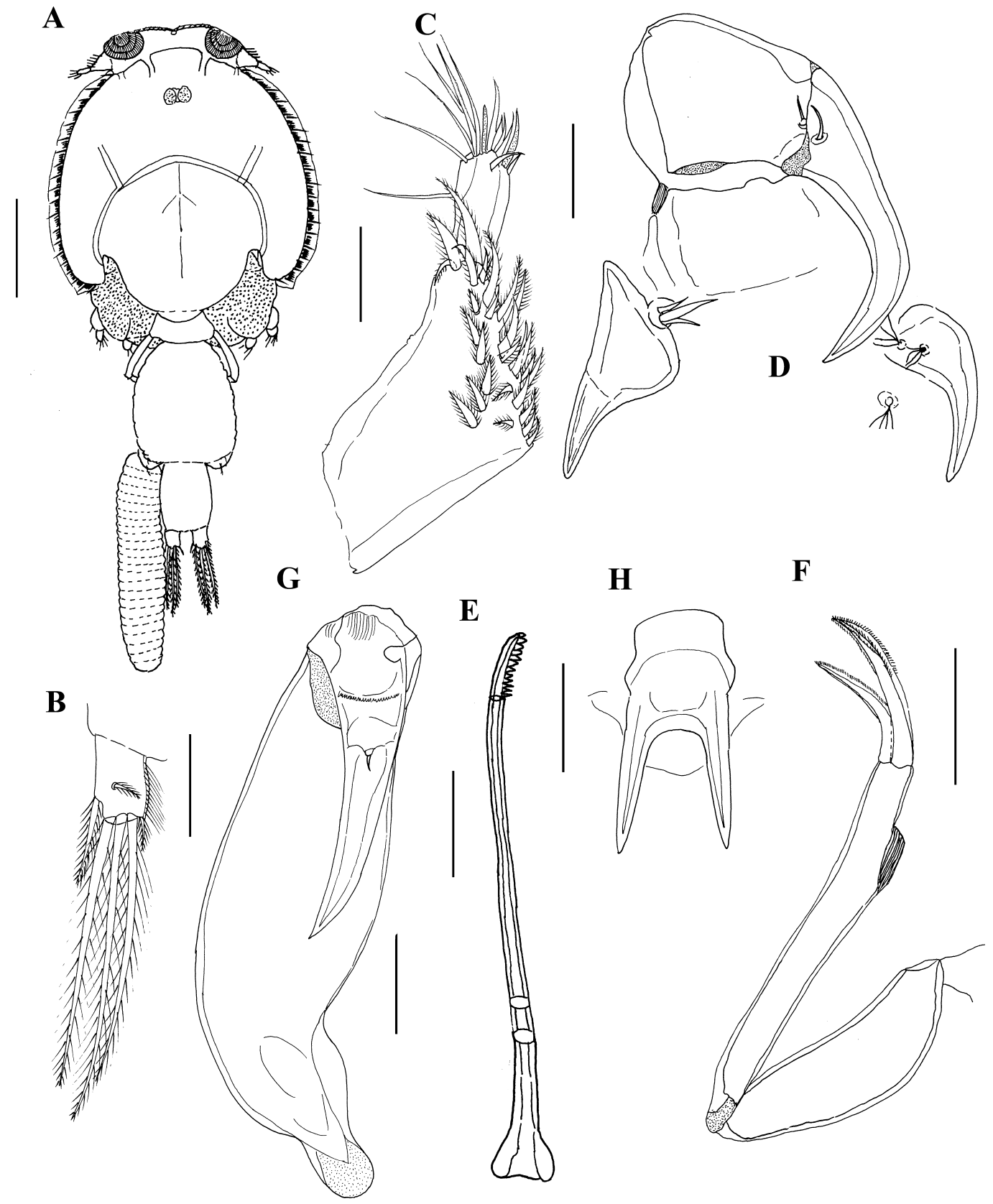

Fig. 5. Caligus ogawai sp. nov., holotype, female (KMNH IvR 500,501). A, habitus; B, caudal ramus; C, antennule; D, antenna, postantennal process and maxillule; E, mandible; F, maxilla; G, maxilliped; $\mathrm{H}$, sternal furca. Scale bars: $1 \mathrm{~mm}$ (A), $0.1 \mathrm{~mm}(\mathrm{~B}-\mathrm{H}), 0.05 \mathrm{~mm}$ (D).

2004). C. quadrigenitalis can be differentiated from all four of these by the rectangular-shape of the genital complex and the extra seta of the maxilliped.

Although many species in Caligus possess an armature of I-0, III on leg 4, only few have such long and slender spines, but these all differs greatly from $C$. quadrigenitalis in the shape of the genital complex: C. longipedis Bassett-Smith, 1898 (subquadrate with protruded corners), C. punctatus Shiino, 1954 (subrectangular and protruded), C. oviceps (slightly rounded with protruded corners), C. patulus Wilson, 1937 (subquadrate with protruded corners), C. pampi (large with posteriorly protruded, long abdomen), and $C$. planktonis Pillai, 1979 (long, broadly rounded) (Ho and Lin 2004a, b).

Etymology. The specific name, an adjective, is the combination of the Latin quadratus (=four cornered), and genitalis (=of the genital area), referring to the rectangular shape of the genital complex.

\section{Caligus ogawai sp. nov.}

(Figs. 5, 6, 7)

Material examined. Holotype: Ovigerous $q(\mathrm{KMNH}$ IvR 500,501), Nagasu, off Shodo Island, Seto Inland Sea, Kagawa Prefecture, Japan (St. 3), 7 October 2008. Paratype: 1 adult but not ovigerous $q$ (KMNH IvR 500,502), Suonada, Seto Inland Sea, Japan (St. 9), 28 October 2010. Allotype: adult $\widehat{\partial}$ (KMNH IvR 500,503), off Hirado Island, Nagasaki Prefecture, Japan (St. 10), 29 October 2010 (Table 1).

Description. Female (based on holotype). Body (Fig. 
5A) $4.65 \mathrm{~mm}$ long excluding caudal setae. Cephalothorax suborbicular, slightly longer than wide, $2.53 \times 2.23 \mathrm{~mm}$. Fourth pediger partly concealed by cephalothorax, wider than long, $0.38,0.40 \times 0.57,0.58 \mathrm{~mm}$. Genital complex slightly tapering anteriorly, longer than wide, $1.09 \times$ $0.90 \mathrm{~mm}$. Abdomen longer than wide, $0.64 \times 0.46 \mathrm{~mm}$. Caudal ramus (Fig. 5B) longer than wide, $0.15 \times 0.12 \mathrm{~mm}$, with 3 long terminal setae, 2 short subterminal setae, and 1 seta located at midlength. Egg string, uniseriate, containing 25 eggs.

Antennule (Fig. 5C) 2-segmented; proximal segment distinctly longer than distal, armed with 27 setae; distal segment armed with subterminal seta on posterior margin and 11 setae plus 2 aesthetascs around apex. Antenna (Fig. 5D) 3-segmented; proximal segment small, unarmed, produced into small dentiform process postero-medially; middle segment subrectangular with 1 small seta distally; distal segment drawn out into curved claw bearing 1 small seta proximally. Postantennal process (Fig. 5D) weakly curved, bearing 2 basal papillae each, with 4 setules; another similar papilla located on nearby sternite. Mandible (Fig. 5E) styliform with 12 marginal teeth subapically. Maxillule (Fig. 5D) comprising dentiform posterior process and anterior papilla bearing 3 short setae. Maxilla (Fig. 5F) slender, 2-segmented; distal segment slender, bearing subterminal hyaline membrane on outer edge and 2 large, curved elements ornamented with serrate hyaline membrane. Maxilliped (Fig. $5 \mathrm{G}$ ) indistinctly 3-segmented; proximal segment robust, unarmed; middle segment flap-like, indistinct; distal subchela comprising incorporated endopodal segment plus distal claw, armed with minute seta at midlength. Sternal furca (Fig. $5 \mathrm{H}$ ) with proximal subquadrate box and long, acutely pointed tines.

Armature on rami of legs 1-4 summarized in Table 3.

Leg 1 (Fig. 6A) protopod consisting of coxa with papilla on outer margin carrying 2 setules, and long, plumose outer (basal) and short, plumose inner (coxal) setae; vestigial endopod tipped with setules; middle 2 of 4 terminal elements on distal margin of second exopodal segment bifid (Fig. 6B). Leg 2 (Fig. 6C) with coxa having large, plumose inner seta; basis with small, naked outer seta; both outer and medial edges of basis fringed with marginal membrane; similar membrane present dorsally on outer margin of first segment of exopod; distal segment of exopod with very small proximal outer spine. Leg 3 (Fig. 6D) protopod with small, plumose outer seta on posterior marginal membrane. Leg 4 (Fig. 6E) with 2-segmented exopod; all outer exopodal spines with pecten at base, outer terminal spine longer than adjacent spines. Leg 5 (Fig. 6F) represented by 2 papillae at posterolateral corner of genital complex, these being tipped with 2 and 1 plumose setae, respectively.

Description. Male, allotype: Body (Fig. 7A) $3.65 \mathrm{~mm}$ long excluding caudal setae. Cephalothorax suborbicular, longer than wide $2.18 \times 1.90 \mathrm{~mm}$ wide. Fourth pediger free, $0.21 \times 0.43 \mathrm{~mm}$, wider than long. Genital complex $0.62 \times$ $0.56 \mathrm{~mm}$, vase-shaped, longer than wide, with legs 5 and 6 projecting slightly. Abdomen $0.50 \times 0.34 \mathrm{~mm}, 2$-segmented, 1st segment small, 2nd segment longer than wide. Caudal ramus $0.17 \times 0.12 \mathrm{~mm}$, longer than wide, setae as in female (Fig. 7B).

Antenna (Fig. 7C) 3-segmented; proximal segment slender, unarmed; middle segment largest, armed with 2 slightly corrugated adhesion pads distally, distal segment armed with basal seta and 2 sclerotized plates. Postantennal process (Fig. 7C) generally as in female, curved, ornamented with hyaline membrane, bearing 2 basal papillae, with 4 setules each, another similar papilla located on nearby sternite. Maxillule (Fig. 7C) distally pointed, with small pore at mid length. Maxilliped (Fig. 7D) robust as in female and bearing 1 seta midlaterally. Leg 5 (Fig. 7E) as in female, represented by 2 papillae at posterolateral corner of genital complex, one bearing 1 small seta and another papilla bearing 1 long and 1 small seta. Leg 6 (Fig. 7E) located near insertion of abdomen, represented by papilla tipped with 1 long seta and 1 small spine.

Remarks. The female of the new species is characterized by the following features: (1) the dentiform process of the antennary proximal segment is tiny and pointed; (2) the maxilliped has one minute seta at the midpoint of the subchela; (3) the sternal furca is long and broad with sharp tines; and (4) the leg 4 exopod is armed with I-0; I,III (IV) spines (Fig. 6E), with the terminal spine markedly longer than the other spines. The male is characterized by having the following features: (1) a simple maxilliped; (2) a 2-segmented abdomen; and (3) leg 6 bearing a long seta and spine. The new species is closely similar to C. savala Gnanamuthu, 1948 in the general body structure and sternal furca but, differs in the tiny, pointed dentiform process of the antennary proximal segment (larger in C. savala). Also, the maxilliped has a minute seta at the middle region of the subchela in C. ogawai, while in C. savala it has a proportionally longer seta located distal to the midlength of the subchela (Gnanamuthu 1948; Pillai 1985). Leg 4 is armed with an equal number of spines in C. savala, but the new species differs in having them arranged as a series of smaller spines leading to a long terminal spine (Fig. 5E).

The new species is similar to the following congeners in the leg 4 armature of the female (I-0; I,III): Caligus latigenitalis Shiino, 1954; C. arii Bassett-Smith, 1898; C. dactylus Ho, Lin and Chang, 2007; C. hobsoni Cressey, 1969, and C. rufimaculatus Wilson, 1905, but can be differentiated from them as follows: from $C$. latigenitalis by the abdomen (rounded $v s$ rectangular in the new species) and sternal furca (simple tines $v s$ tines with flanges in the new species); from $C$. arii by the abdomen (larger and quite long $v s$ small and rectangular in the new species) and the postantennal process (absent $v s$ present in the new species); from $C$. hobsoni by the abdomen (2-segmented vs 1-segmented in the new species); and from C. rufimaculatus by the sternal furca (short, blunt tines $v s$ long, pointed tines with flanges in the new species) (Cressey 1969; Izawa and Choi 2000; Suàrez Morales et al. 2003; Ho and Lin 2004a).

Concerning the male characteristics, C. latigenitalis is again similar to the present new species, but the former markedly differs from the latter in the structure of the maxilliped. In C. latigenitalis, the maxilliped has a myxal area on 

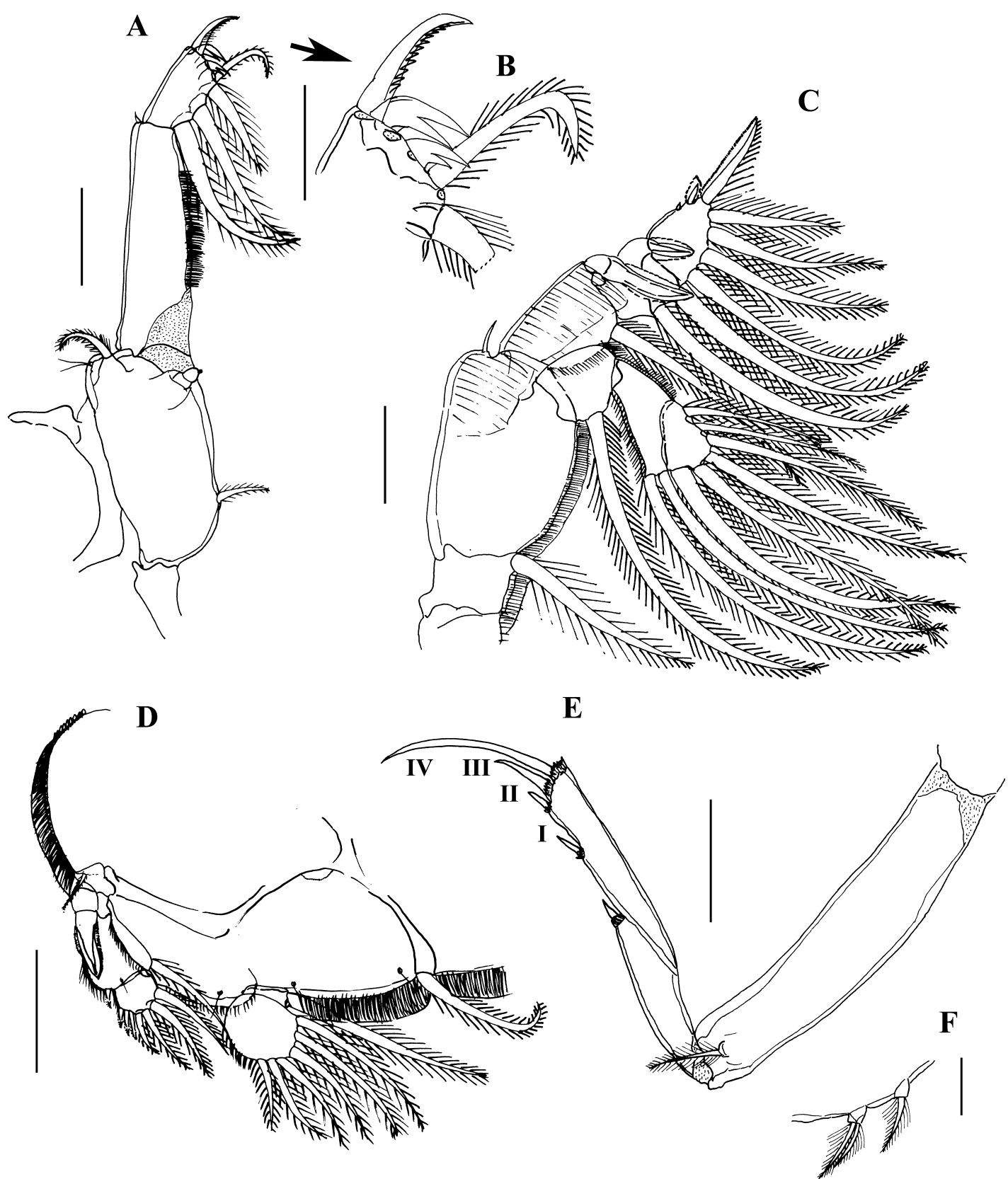

Fig. 6. Caligus ogawai sp. nov., holotype, female (KMNH IvR 500,501). A, leg 1; B, distal tip of exopod of leg 1 enlarged; C, leg 2; D, leg 3; E, leg 4; F, leg 5. Scale bars: $0.1 \mathrm{~mm}(\mathrm{~A}-\mathrm{F}), 0.05 \mathrm{~mm}(\mathrm{~B})$.

Table 3. Caligus ogawai sp. nov: armature on rami of legs 1-4 (Roman and Arabic numerals indicate spines and setae, respectively).

\begin{tabular}{ccccc}
\hline & Coxa & Basis & Exopod & Endopod \\
\hline Leg 1 & $0-0$ & $1-1$ & 1-0; III, I, 3 & (vestigial) \\
Leg 2 & $0-1$ & $1-0$ & I-1, I-1, II, I, 5 & $0-1 ; 0-2 ; 6$ \\
Leg 3 & $0-1$ & $1-0$ & I-0; I-1; III, 4 & $0-1 ; 6$ \\
Leg 4 & $0-0$ & $1-0$ & I-0; I, III & (absent) \\
\hline
\end{tabular}

the stout corpus comprising three unequal protuberances (Izawa and Choi 2000), but it is simple with no protuberances in the new species (Fig. 7D). All these congeners here considered have been found exclusively as parasites on teleosts, except for C. latigenitalis and C. rufimaculatus, which have also been reported from plankton in Japan (Venmathi Maran et al. 2012a) and Mexico (Suàrez Morales et al. 2003), respectively.

Etymology. This new species is named in honor of retired Prof. Kazuo Ogawa (University of Tokyo); currently at Meguro Parasitological Museum, in recognition of his major contributions to marine parasitology. 


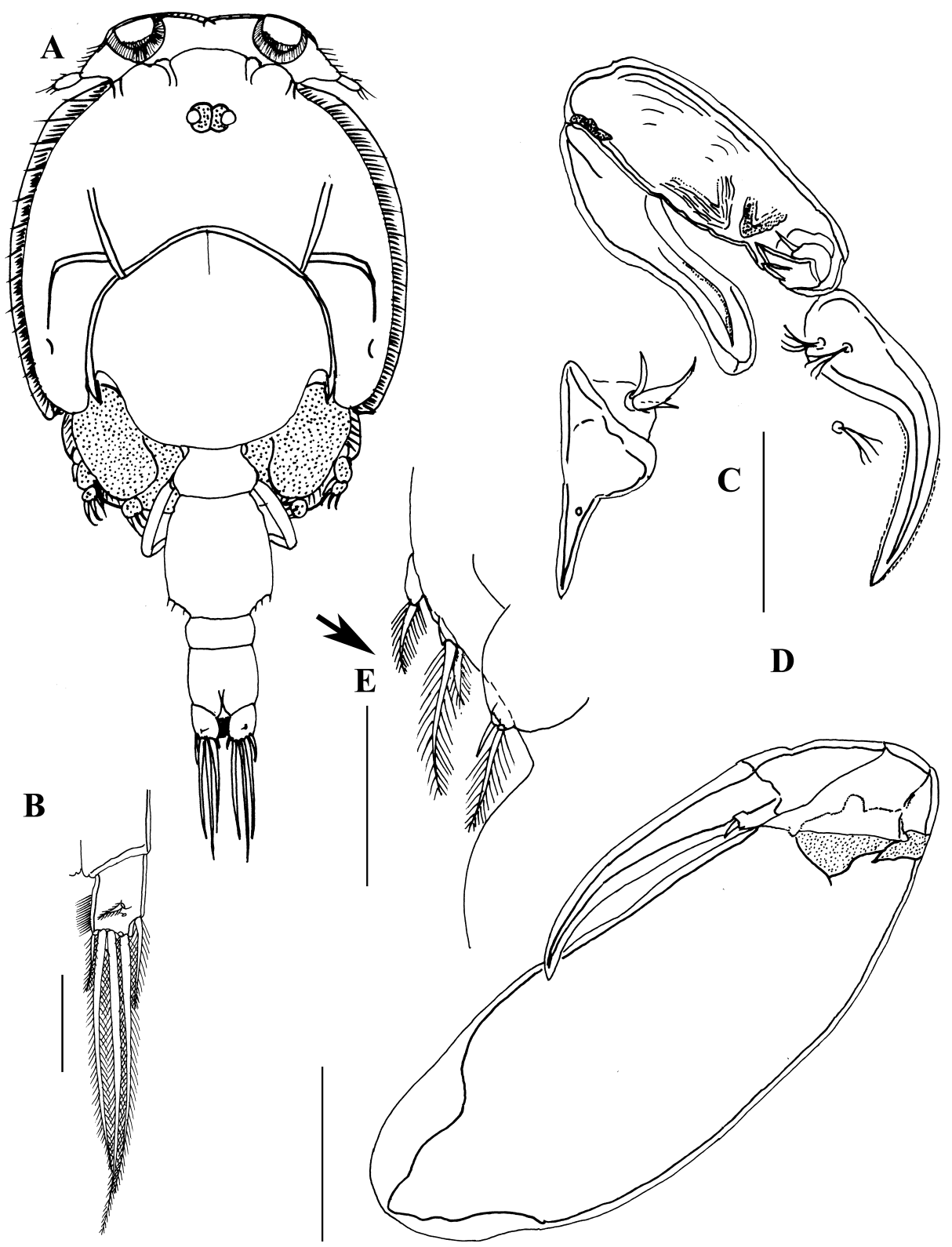

Fig. 7. Caligus ogawai sp. nov., holotype, male (KMNH IvR 500,502). A, habitus; B, caudal ramus; C, antenna; D, maxilliped; E, legs 5 and 6. Scale bars: $1 \mathrm{~mm}$ (A), $0.1 \mathrm{~mm}$ (B-E).

\section{Caligus orientalis Gusev, 1951}

(Fig. 8A, B)

Caligus orientalis Gusev, 1951: 411; Brandes 1956: 173; Markevich 1956: 184; Yin 1962: 41; Yamaguti 1963: 57; Hwa 1965: 48; Margolis and Parker 1966: 311; Suzumoto 1974: 23; Urawa et al. 1979: 139; Matumoto 1980: 143; Li 1984: 157; Urawa and Kato 1991: 161; Nagasawa 1994: 83; Kim 1998: 664; Lin and Ho 1998a: 200, 1998b: 96.

Caligus laticorpus Shen, 1957: 354; Yamaguti 1963: 55; Yoda 1973: 98; Nagasawa et al. 2010: 103.

Material examined. One adult $\odot$ (XOB-PC 11), Amoy (=Xiamen), Fujian Province, China (St. 1), 20 September 2008; 1 adult $\widehat{\partial}$ (KMNH IvR 500,504), Ariake Sea, Saga Prefecture, Japan (St. 2), 6 July 2008 (Table 1).

Description. Female. Body (Fig. 8A) $2.68 \mathrm{~mm}$ long, excluding caudal setae. Cepahalothorax slightly longer than wide, $1.60 \times 1.57 \mathrm{~mm}$. Fourth pediger wider than long, $0.15 \times 0.32 \mathrm{~mm}$. Genital complex subrectangular, slightly wider than long, $0.64 \times 0.76 \mathrm{~mm}$, with rounded posterolateral corners. Abdomen small, $0.28 \times 0.31 \mathrm{~mm}$, unsegmented. Caudal ramus wider than long, armed with 3 short and 3 long plumose setae.

Male. Body (Fig. 8B) $3.01 \mathrm{~mm}$ long, excluding caudal setae. Cephalothorax longer than wide, $1.98 \times 1.71 \mathrm{~mm}$. Fourth pediger wider than long, $0.17 \times 0.40 \mathrm{~mm}$. Genital complex wider than long, $0.51 \times 0.70 \mathrm{~mm}$, with indented lateral margins and sharp, acute posterolateral projections marking leg 5. Abdomen small, $0.32 \times 0.40 \mathrm{~mm}$, distinctly 2 -segmented with large anal somite. Caudal ramus as in female.

Remarks. This is the first record of male Caligus orientalis from Japan and the second report from China in 

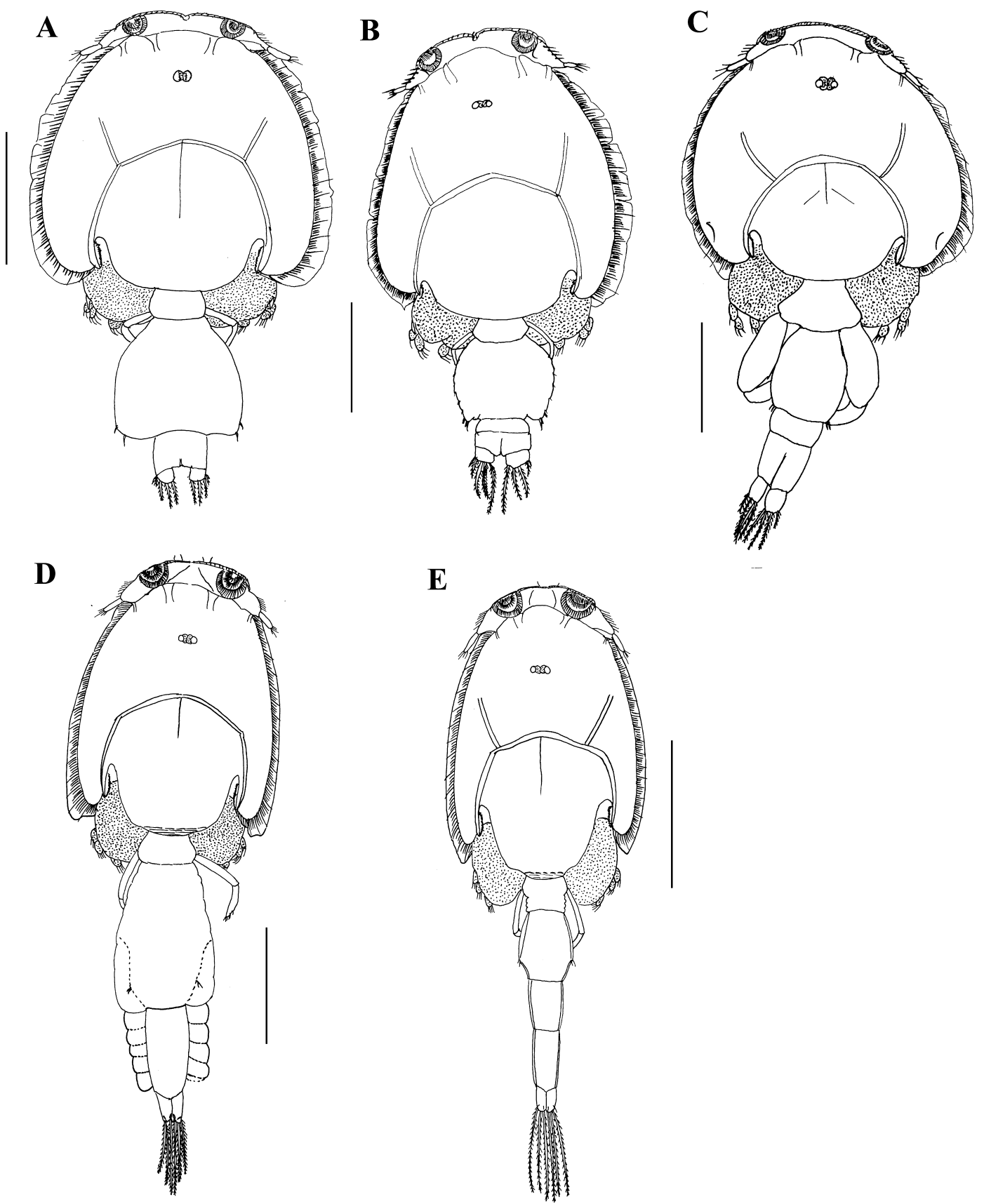

Fig. 8. Three previously described species of Caligus found in plankton samples. A, Caligus orientalis Gusev, 1951, female (KMNH IvR 500,503), habitus, dorsal view; B, C. orientalis, male (KMNH IvR 500,504), habitus, dorsal view; C, C. rotundigenitalis Yu, 1933, male (XOBPC12), habitus, dorsal view; D, C. undulatus Shen and Li, 1959, female (KMNH IvR 500,505), habitus, dorsal view; E, C. undulatus, male (KMNH IvR 500,506), habitus, dorsal view. Scale bars: $1 \mathrm{~mm}(\mathrm{~A}-\mathrm{E}), 0.5 \mathrm{~mm}(\mathrm{C})$.

plankton samples. Both sexes of C. orientalis were reported recently from plankton samples at the mouth of the Mankyong River, Korea (Venmathi Maran and Ohtsuka 2008), where the number of males exceeded that of females. The present male $(3.01 \mathrm{~mm})$ is larger than the present female $(2.68 \mathrm{~mm})$, in accordance with previous reports (Ho and Lin 2004a; Venmathi Maran and Ohtsuka 2008).

Distribution. Caligus orientalis is a serious pest of cultured mullet Mugil cephalus Linnaeus, 1758 in Korea (Kim 1998). It is a common parasite in Asia, severely infecting the freshwater fish common carp Cyprinus carpio Linnaeus, 1758 in aquaculture facilities (Suzumoto 1974; Matumoto
1980), and also in marine waters (Hwa 1965; Urawa et al. 1979; Urawa and Kato 1991; Kim 1998; Lin and Ho 1998a, b), sometimes causing mass mortality (Kim 1998). The hosts of C. orientalis and its biology have been reviewed (Nagasawa 2004). It is well distributed in Japan (Nagasawa et al. 2010), Korea (Kim 1998; Venmathi Maran and Ohtsuka 2008), China (Shen 1957; Hwa 1965; present study), Taiwan (Lin and Ho 1998a,b) and the Russian Far-East (Gusev 1951). The regular occurrence of this species in plankton suggests that it readily detaches from the host and actively swims in the water column. 


\section{Caligus rotundigenitalis Yü, 1933}

(Fig. 8C)

Caligus rotundigenitalis Yü, 1933: 118; Rangnekar 1959: 43; Yamaguti 1963: 59; Pillai and Natarajan 1977: 31; Pillai 1985: 348; Ho and Sey 1996: 65; Ho et al. 2000: 177; Ho and Lin 2001: 193; Grobler 2004: 141; Venmathi Maran et al. 2009: 797; Nagasawa et al. 2010: 103.

Caligus multispinosus (not Shen, 1957): Lin et al. 1994: 259; 1997: 1483; Lin and Ho 1998b: 96.

Material examined. One adult $\hat{\sigma}$ (XOB-PC12), Amoy (=Xiamen), Fujian Province, China (St. 1), 20 September 2008 (Table 1).

Description. Male. Body (Fig. 8C) $1.38 \mathrm{~mm}$ long, excluding caudal setae. Cephalothoracic shield slightly wider than long, $0.71 \mathrm{~mm} \times 0.75 \mathrm{~mm}$. Fourth pediger wider than long, $0.14 \mathrm{~mm} \times 0.30 \mathrm{~mm}$. Genital complex subquadrate, small, longer than wide, $0.24 \mathrm{~mm} \times 0.20 \mathrm{~mm}$. Abdomen distinctly 2 -segmented, longer than wide, $0.20 \mathrm{~mm} \times 0.12 \mathrm{~mm}$. Caudal ramus longer than broad, $0.08 \mathrm{~mm} \times 0.05 \mathrm{~mm}$, armed with 3 short and 3 long plumose setae.

Remarks. This is the first record of $C$. rotundigenitalis in a plankton sample. Four other species of Caligus have hitherto been reported from plankton samples in China (Shen and Li 1959), including three species of which the hosts are as yet unknown, viz., C. aduncus Shen and Li, 1959, C. costatus Shen and Li, 1959, and C. undulatus Shen and Li, 1959.

Distribution. Caligus rotundigenitalis is one of the most common caligids on cultured and wild fishes in Asia (Ho et al. 2000; Venmathi Maran et al. 2009; Nagasawa et al. 2010). It shows low host-specificity, utilizing a total of 32 fish species in 19 families as hosts in Taiwan (Ho et al. 2000).

\section{Caligus undulatus Shen and Li, 1959} (Fig. 8D, E)

Caligus undulatus Shen and Li, 1959: 12; Yamaguti 1963: 60; Pillai 1966: 123; 1985: 360; Montú 1982: 329; Venmathi Maran and Ohtsuka 2008: 202; Nagasawa et al. 2010: 103.

Material examined. Two adult $q \circ$ (one ovigerous) $(\mathrm{KMNH}$ IvR 500,505) and one adult $\delta$ (KMNH IvR 500,506), Takamatsu Port, Kagawa Prefecture, Japan (St. 6), 3 October 2008 (Table 1).

Description. Female. Body (Fig. 8D) 4.26, $4.29 \mathrm{~mm}$ long, excluding caudal setae. Cephalothoracic shield longer than wide, $2.02-2.05 \times 1.51-1.53 \mathrm{~mm}$. Fourth pediger wider than long, $0.27-0.29 \times 0.37-0.39 \mathrm{~mm}$. Genital complex longer than wide with irregular lateral margins, $1.21-1.23 \times 0.89-0.91 \mathrm{~mm}$. Abdomen long, 0.75-0.77×0.31$0.34 \mathrm{~mm}$. Caudal ramus longer than wide, carrying 3 long terminal and 3 short subterminal setae.

Male. Body (Fig. 8E) $3.54 \mathrm{~mm}$ long, excluding caudal setae. Cephalothoracic shield longer than wide, $1.89 \times$ $1.29 \mathrm{~mm}$. Fourth pediger slightly constricted anteriorly. Genital complex longer than wide, $0.56 \times 0.39 \mathrm{~mm}$. Abdomen distinctly 2 -segmented, subequal in length and width.
Caudal ramus as in female.

Remarks. The present female specimens generally agree in size and morphology with those recently reported from plankton samples in Japan and Korea (Venmathi Maran and Ohtsuka 2008), but some discrepancies are observed between the present specimens and the specimen reported from China by Shen and Li (1959). The present female specimens lack prominent ridges on the genital complex, which are shown on the illustrations given by Shen and Li (1959), but not on specimens from India (Pillai 1966). The present male specimen $(3.54 \mathrm{~mm})$ is larger than one from China (3.08 mm) (Shen and Li 1959), but similar to others from India $(3.50 \mathrm{~mm})$ (Pillai 1966), Japan $(3.50 \mathrm{~mm})$, and Korea (3.52 mm) (Venmathi Maran and Ohtsuka 2008).

Distribution. Caligus undulatus was originally discovered in plankton samples from China (Shen and Li 1959) and was subsequently found in Brazil (Montú 1982), India (Pillai 1966, 1985), Japan, and Korea (Nagasawa et al. 2010). This species has been found most frequently in plankton, and it may have unique aspects to its life history.

\section{Lepeophtheirus semicossyphi Yamaguti, 1939}

(Fig. 9A)

Lepeophtheirus semicossyphi Yamaguti, 1939: 443; Shiino 1963: 409; Yamaguti 1963: 409; Kim 1998: 717.

Material examined. One adult $\odot$ (KMNH IvR 500,507), off Iheya Island, Okinawa Prefecture, Japan (St. 8), 22 May 2008 (Table 1).

Description. Female. Body (Fig. 9A) $5.06 \mathrm{~mm}$ long excluding caudal setae. Cephalothorax suborbicular $3.03 \times$ $2.89 \mathrm{~mm}$, slightly longer than wide. Fourth pediger $0.51 \times$ $0.85 \mathrm{~mm}$, wider than long. Genital complex globose, $1.42 \times$ $1.70 \mathrm{~mm}$, wider than long, with convex lateral margins and 2 prominent posterolateral projections. Abdomen small, $0.20 \times 0.32 \mathrm{~mm}$, wider than long. Caudal ramus $0.09 \times$ $0.12 \mathrm{~mm}$, wider than long, with 3 long and 3 short plumose setae.

Remarks. This is the first record of adult Lepeophtheirus in a plankton sample. Lepeophtheirus semicossyphi is parasitic on the wrasse Semicossyphus reticulatus (Valenciennes, 1839) and was originally reported from Tarumi, Hyogo Prefecture, Japan (Yamaguti 1939). It was subsequently reported from the same host elsewhere in Japan (Shiino 1963) and in Korea (Kim 1998).

\section{Metacaligus uruguayensis Thomsen, 1949} (Fig. 9B)

Caligus (Metacaligus) uruguayensis Thomsen, 1949: 3; Pillai 1963: 68; Ho and Bashirullah 1977: 708; Boxshall and Montú 1997: 1-225.

Caligus longicervicis Gnanamuthu 1950: 115; Kirtisinghe 1964: 65 .

Material examined. One adult $q$ (KMNH IvR 500,508), Osaka Port, Osaka Prefecture, Japan (St. 4), 5 

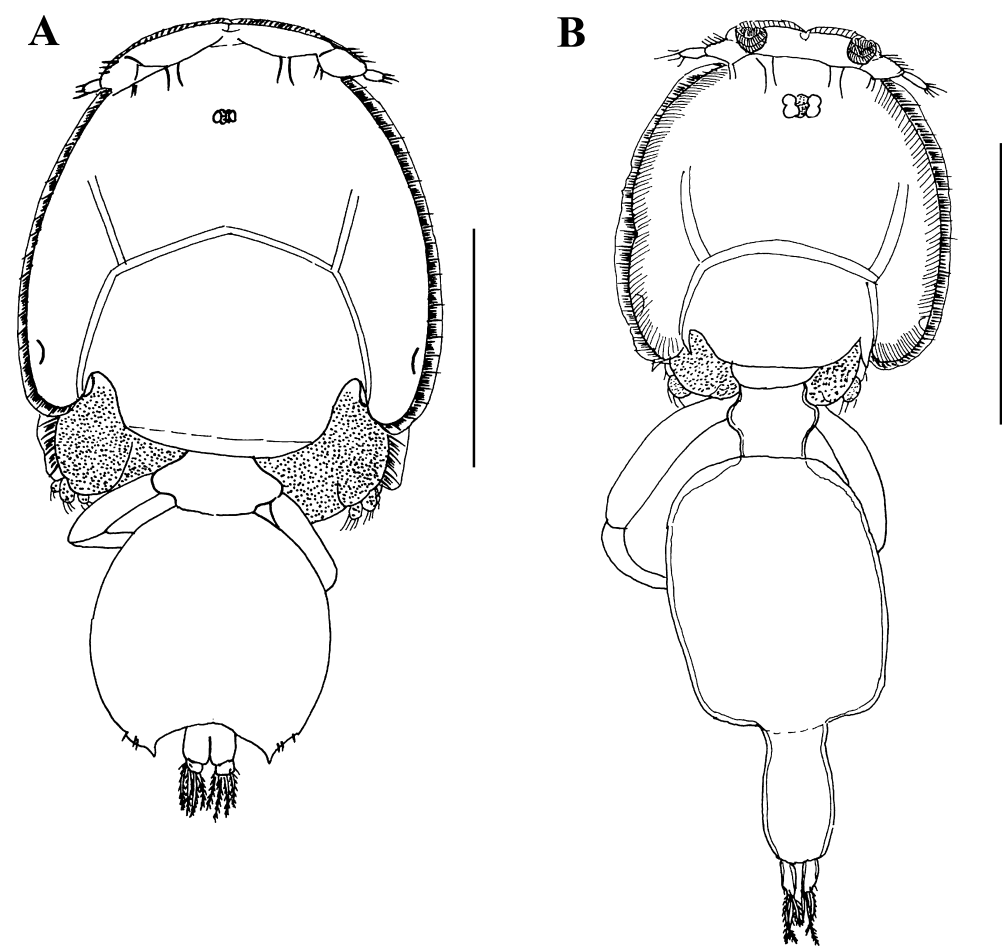

Fig. 9. Two other caligid genera from plankton samples. A, Lepeophtheirus semicossyphi Yamaguti, 1939, female (KMNH IvR 500,507), habitus, dorsal view; B, Metacaligus uruguayensis Thomsen, 1949, female (KMNH IvR 500,508), habitus, dorsal view. Scale bars: $1 \mathrm{~mm}$ (A-B).

October 2008 (Table 1).

Description. Female. Body (Fig. 9B) $4.09 \mathrm{~mm}$ long excluding caudal setae. Cephalothoracic shield subcircular, slightly longer than wide, $1.59 \times 1.48 \mathrm{~mm}$. Fourth pediger wider than long, $0.37 \times 0.44 \mathrm{~mm}$. Genital complex subquadrate, longer than wide, $1.23 \times 1.01 \mathrm{~mm}$. Abdomen longer than wide, $0.67 \times 0.36 \mathrm{~mm}$, unsegmented. Caudal ramus longer than wide, $0.14 \times 0.07 \mathrm{~mm}$, armed with 3 short subterminal and 3 long terminal setae.

Remarks. Five species of Metacaligus are currently known worldwide: M. rufus (Wilson 1908) from North America; M. uruguayensis Thomsen, 1949 from Uruguay (Thomsen 1949), India (Pillai 1963), Sri Lanka (Kirtisinghe 1964), Venezuela (Ho and Bashirullah 1977), and Brazil (Boxshall and Montú 1997); M. unguidentatus Rangnekar and Murti, 1950 from India (Pillai 1985); M. hilsae (Shen, 1957) from China (Shen 1957); and M. latus Ho and Lin, 2002 from Taiwan (Ho and Lin 2002). This is the first record of this species in Japanese waters.

Distribution. Metacaligus has been regarded as hostspecific to the genus Trichiurus Linnaeus, 1758. It has so far been found on T. haumela (Forsskål, 1775) in India (Gnanamuthu 1950), T. lepturus Linnaeus, 1758 in Uruguay (Thomsen 1949) and Venezuela (Ho and Bashirullah 1977), and T. savala Cuvier, 1829 in India (Pillai 1963) and Sri Lanka (Kirtisinghe 1964). However, it was also recorded from Lobotes surinamensis (Bloch, 1790) in Taiwan (Ho and Lin 2002).

Family Pandaridae Milne-Edwards, 1840 Pandarus satyrus Dana, 1852

(Figs. 10, 11)
Pandarus satyrus Dana, 1852: 1368; Brady 1883: 134; Bassett-Smith 1899: 467; Wilson 1907: 415; 1914: 71; Yamaguti 1936: 5; Bere 1936: 595; Shiino 1957: 364, 1959a: 315, 1959b: 352, 1960: 493; Ho 1963: 90; Cressey 1967: 15; Benz 1981: 966.

Material examined. One young male (KMNH IvR 500,509), off Akuseki Island, Tokara Islands, Kagoshima Prefecture, Japan (St. 7), 27 May 2008 (Table 1).

Description. Male. Body (Fig. 10A) $6.31 \mathrm{~mm}$ long, excluding caudal setae. Cephalothorax narrow, longer than wide, $4.00 \times 2.87 \mathrm{~mm}$. Second pediger extended posterolaterally into pair of lobe-like structures. Genital complex wider than long, $1.23 \times 1.50 \mathrm{~mm}$. Abdomen small, wider than long, $0.36 \times 0.76 \mathrm{~mm}$. Caudal ramus small and wide, $0.28 \times$ $0.32 \mathrm{~mm}$, armed with 4 long and 2 small setae.

Antennule (Fig. 10B) 2-segmented; proximal segment long with 9 plumose and 5 hirsute setae; distal segment small with 5 long, hirsute setae and 3 short setae. Antenna (Fig. 10C) indistinctly 3-segmented; proximal segment unarmed; middle segment unarmed, lacking posterior process; distal segment with curved claw bearing 1 proximal and 1 medial seta. Post-antennal process (Fig. 10C) large, modified as adhesion pad, bearing 2 basal papillae on sternum with 4 setules each. Maxillule (Fig. 10C) represented by small, rounded process with 2 small setae. Oral cone (Fig. 10D) long; 2 large adhesion pads present on ventral surface of cephalothorax lateral to oral cone. Mandible (Fig. 10E) slender, with 10 marginal teeth subapically. Maxilla (Fig. 10F) 2-segmented; proximal segment robust; distal segment broad, with 2 broad claws ornamented with hyaline membrane distally and patchy spinules at base. Maxilliped (Fig. 


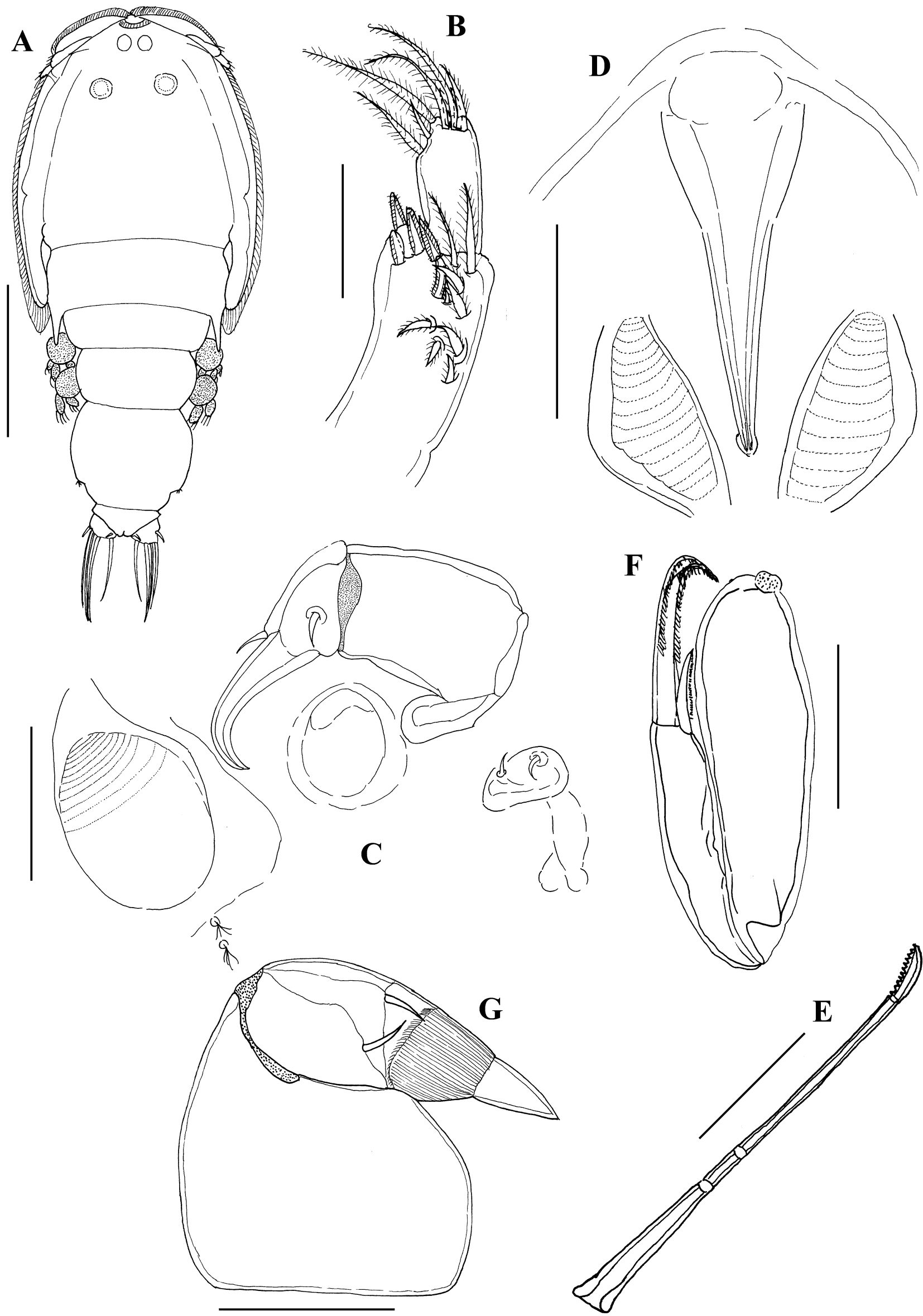

Fig. 10. Pandarus satyrus Dana, 1852, young male (KMNH IvR 500,509). A, habitus; B, antennule; C, antenna, post-oral process, and maxillule; D, oral cone; E, mandible; F, maxilla; G, maxilliped. Scale bars: $2.5 \mathrm{~mm}(\mathrm{~A}), 0.1 \mathrm{~mm}(\mathrm{~B}-\mathrm{G}), 0.2 \mathrm{~mm}(\mathrm{D}), 0.05 \mathrm{~mm}$ (E). 
A
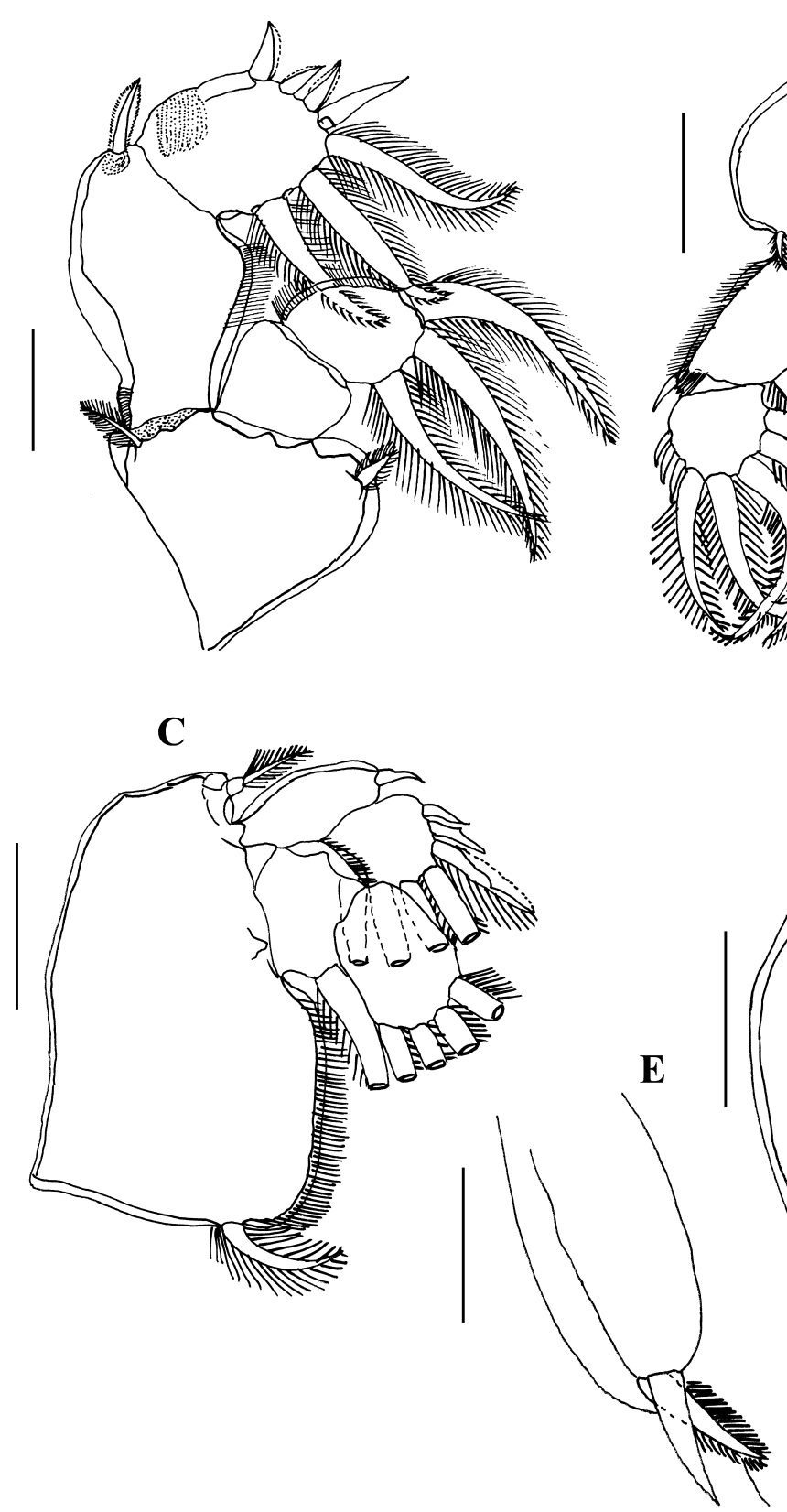

B

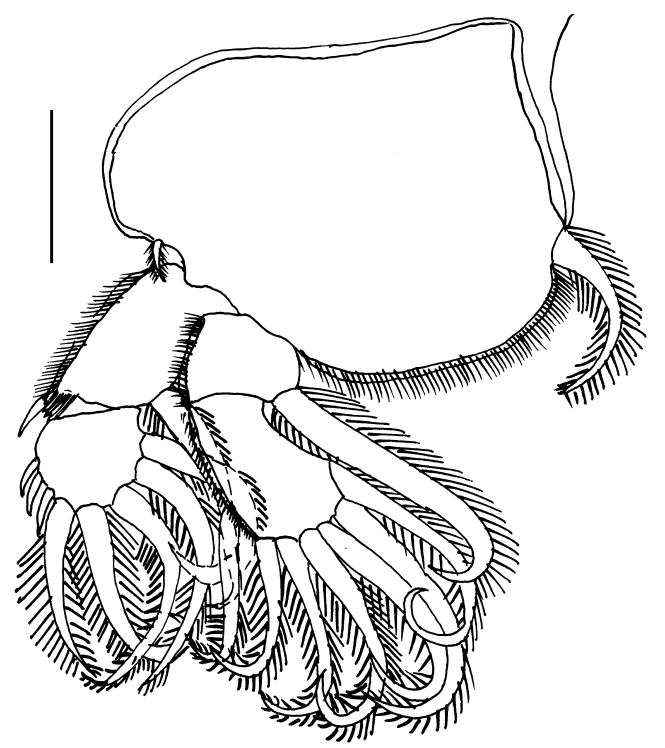

Fig. 11. Pandarus satyrus Dana, 1852, young male (KMNH IvR 500,509). A, leg 1; B, leg 2; C, leg 3; D, leg 4; E, leg 5 . Scale bars: 0.1 mm (A-E).

Table 4. Pandarus satyrus Dana, 1852: armature on rami of legs 1-4 (Roman and Arabic numerals indicate spines and setae, respectively).

\begin{tabular}{ccccc}
\hline & Coxa & Basis & Exopod & Endopod \\
\hline Leg 1 & $0-0$ & $1-1$ & I-0; III,4 \\
Leg 2 & $0-0$ & $1-1$ & I- $1 ;$ III,5 \\
Leg 3 & $0-0$ & $1-1$ & I-0; III,4 & $0-1 ; 7$ \\
Leg 4 & $0-0$ & $1-0$ & I-0; IV,3 \\
\hline
\end{tabular}

10G) incompletely 3-segmented; proximal segment largest; middle segment small, partly fused with distal segment to form subchela; distal segment short, robust, pointed claw armed with 2 setae subterminally. Sternal furca absent.

Armature on rami of legs 1-4 summarized in Table 4.

Leg 1 (Fig. 11A) protopod with basis bearing 1 outer and
1 inner plumose seta; exopod 2-segmented, distal segment bearing 3 long, thick plumose setae; endopod 2-segmented, distal segment carrying 3 long, thick plumose setae. Leg 2 (Fig. 11B) protopod with basis bearing small outer and long, plumose inner setae; exopod 2-segmented; distal segment carrying 3 small spines and 5 long setae; endopod 
2 -segmented, bearing 7 setae distally. Leg 3 (Fig. 11C) protopod with basis bearing 1 outer and 1 inner plumose seta; exopod 2-segmented, proximal segment with small spine; distal segment carrying 2 small and 1 long spines. Leg 4 (Fig. 11D) protopod with basis bearing outer plumose seta; exopod 1-segmented with 3 small and 1 long spines and fringed with hyaline membrane laterally. Leg 5 (Fig. 11E) represented by papilla bearing 1 plumose and 1 pinnate seta.

Remarks. Adults of $P$. satyrus differ from the present young male in the following characters: (1) the 2-segmented abdomen ( $v s$ non-segmented), and (2) the setal formula of the second, third, and fourth legs ( $v s$ fewer elements) (cf. Shiino 1954b). In our previous study, we collected many chalimus stages and adult males of Pandarus sp. in plankton samples from Japan (Venmathi Maran and Ohtsuka 2008). Pandarus is host-specific to elasmobranchs (Cressey 1967; Benz 1981, 1992). Normally they would be firmly attached by their maxillipeds to the body surface of sharks (Benz 1981, 1992; Benz et al. 2003), but if accidentally detached they can become planktonic (Venmathi Maran and Ohtsuka 2008). A separate genus Nogaus Leach, 1816 (or Nogagus), was established for free-swimming specimens in the family Pandaridae by Kabata (1979), but still several nominal species of Nogaus have yet to be assigned to a valid genus (cf. Boxshall and Halsey 2004).

Distribution. Shiino (1954b) found both sexes of $P$. satyrus on the body surface of the smooth hammerhead shark Sphyrna zygaena (Linnaeus, 1758) and the blue shark Prionace (=Isuropis) glauca (Linnaeus, 1758) in Japanese waters. Pandarus satyrus is cosmopolitan, recorded from the Atlantic coast of the United States (Wilson 1914), Japan (Shiino 1954b, 1959a, b, 1960), the Gulf of Mexico, and the IndoPacific and Atlantic Oceans (Cressey 1967).

\section{Discussion}

The adaptive significance of pelagic adults of caligiform copepods has been matter of discussion, since the first discovery of a pelagic adult male of Caligus hyalinus Cherniavsky, 1868 (Cherniavsky 1868). Kabata (1979) regarded such planktonic occurrences as accidental, because the mouthparts of the planktonic caligids are suitable only for feeding on host fishes. However, Venmathi Maran and Ohtsuka (2008) pointed out the following possibilities for the adaptive significance of the pelagic phase: (1) escape from the host, (2) host switching, (3) change of life mode, and (4) accidental detachment from host. According to Ohtsuka et al. (2004), two types of life modes of females occur in the poecilostomatoid copepod family Ergasilidae. Females of some species never detach from the host, whereas those of others seem to attach themselves to the host only while feeding and are otherwise free-swimming.

Some species of Caligus have been encountered only as pelagic forms rather than as parasites on host fish: C. aduncus, C. costatus, C. hyalinae Heegaard, 1966, C. tripedalis Heegaard, 1972, and C. undulatus (Ho and Lin 2004b; Venmathi Maran and Ohtsuka 2008; Venmathi Maran et al. 2012a). In particular, there has been no record of fish hosts for C. undulatus, although it has been frequently found in plankton samples mainly from East Asia (Shen and Li 1959; Venmathi Maran and Ohtsuka 2008; Venmathi Maran et al. 2012a; present study). Likewise, Gnanamuthu (1948) found 12 females and 5 males of $C$. savala in plankton samples from off Madras, although, subsequently it was also recorded as parasitic on the ribbon fish Trichiurus savala along the Madras coast (Gnanamuthu 1948), and later also from the coast of Kerala (Pillai 1985). Recent studies have shown that adults not only of Caligus but of other caligiforms occur freely in the water column (Ho and Lin 2004b; Venmathi Maran and Ohtsuka 2008; present study). Lepeophtheirus and Metacaligus were newly found as pelagic forms in the present study. Other caligiforms, too, may eventually be recovered from plankton samples. Active swimming seems to be possible for all caligiforms with well developed legs bearing plumose setae.

Recently, Hayward et al. (2008) reported a unique life cycle for C. chiastos on farmed southern bluefin tuna Thunnus maccoyii (Castelnau, 1872) off South Australia. They found a prevalence of up to $20 \%$, with a grand mean intensity and abundance of sea lice per infected tuna of 5.77 and 1.15 , respectively. The maximum intensity was up to 42 individuals per host, but, no attached chalimus stages were detected. This implies that all the adults had transferred from other uncaged host fishes via the water column to cultured bluefin tuna by active swimming after molting from the fourth chalimus stage (Hayward et al. 2011). This copepod also infects other wild fish occurring around the cages such as Degen's leatherjacket Thamnaconus degeni (Regan, 1903), the scad Trachurus sp., and some elasmobranchs and benthic teleosts (Hayward et al. 2008). A similar situation has been observed for C. sclerotinosus Roubal, Armitage and Rhode, 1983 on the red seabream Pagrus major (Temminck and Schlegel, 1844) cultured in Japan and in Korea: high prevalence and intensity of adults on red seabream but almost no chalimi was located on red seabream (Venmathi Maran et al. 2012b). We have confirmed that the two naupliar and one copepodid stages of C. sclerotinosus are also present as free-swimming stages as like life history of other caligids, but, chalimi between these free-swimming and final stages are apparently missing on red seabream (Venmathi Maran et al. 2012b). These two examples support our hypothesis that host switching is common in some caligids, but it is also possible that these are special cases related to aquaculture.

As for Lepeophtheirus, several developmental stages of $L$. salmonis have been reported from plankton samples taken near aquaculture facilities on the west coast of Ireland (Costello et al. 1998) and Scotland (Penston et al. 2004). In the present study we found adult L. semicossyphi in plankton samples whereas it is well known as a parasite of Semicossyphus reticulatus in the Pacific Ocean (Yamaguti 1939; Shiino 1963; Kim 1998).

Sea louse copepodids tend to orientate themselves near the surface during daylight (Copley et al. 2005), hence developmental stages are vulnerable to be caught in plankton 
sample (Costello et al. 1998; Penston et al. 2004). They move towards a light source and into areas of low pressure (Bron et al. 1993). Based on these facts, in our study too, we have collected caligiform copepods from plankton samples both by day and at night (Venmathi Maran and Ohtsuka 2008; Venmathi Maran et al. 2012a; present study). Hull et al. (1998) reported on mating experiments that indicated that adults of $L$. salmonis are actively involved in host transfer. They further elucidated that adult males have more to gain than females from inter-host transfer because males mate more times than females. By leaving a host after mating, a male may encounter new hosts carrying unmated females. Males (80\%) were found more than females in our last study (Venmathi Maran and Ohtsuka 2008), but in the present study as well as another recent report (Venmathi Maran et al. 2012a), the sexes were taken in more or less equal numbers.

Apart from caligids, a member of the family Pandaridae was also collected during this study. In our last report (Venmathi Maran and Ohtsuka 2008), two males and 16 chalimi were found in plankton samples from Okinawa, Japan. The present find is thus the second record of Pandarus in plankton samples from Japan. The frequent occurrence of pelagic caligiform adults and pandarids suggest that they normally occur both in the water column and on host fish. The reasons for this are still unclear, and a detailed study involving as laboratory experiments are required to understand and confirm the planktonic occurrence of any particular species of parasitic copepod (Venmathi Maran et al. 2012a).

\section{Acknowledgments}

We would like to thank the captain and crew members of TR/V “Toyoshio-maru”, Hiroshima University, for their cooperation during the cruises. In addition, we would like to thank Prof. C. Hwang (Wenzhou Medical College, China) for his encouragement during our visit to China. We thank Dr. Geoffrey A. Boxshall for his critical comments on this manuscript. This study was partially supported by grants from the Korea Institute of Ocean Science and Technology awarded to BAVM (PK08080, PE98785, PE98811) and from the Japan Society for the Promotion of Science (Nos. 20380110, 23658162) and the Ministry of Environment, Japan (D-072) to SO.

\section{References}

Bassett-Smith, P. W. 1899. A systematic description of parasitic Copepoda found on fishes, with an enumeration of the known species. Proceedings of the Zoological Society of London 2: 438-507.

Benz, G. W. 1981. Observations on the attachment scheme of the parasitic copepod Pandarus satyrus (Copepoda: Pandaridae). The Journal of Parasitology 67: 966-967.

Benz, G. W. 1992. How Pandarus species (Copepoda: Pandaridae) attach to their shark hosts. The Journal of Parasitology 78: 368-370.

Benz, G. W., Mollet, H. F., Ebert, D. A., Davis, C. R. and Van Sommera, S. V. 2003. Five species of parasitic copepods (Siphonostomatoida:
Pandaridae) from the body surface of a white shark captured in Morro Bay, California. Pacific Science 57: 39-43.

Bere, R. 1936. Parasitic copepods from the Gulf of Mexico fish. American Midland Naturalist 17: 577-625.

Boxshall, G. A. and Halsey, S. H. 2004. An Introduction to Copepod Diversity. The Ray Society, London, $966 \mathrm{pp}$.

Boxshall, G. A. and Montú, M. A. 1997. Copepods parasitic on Brazilian coastal fishes: a handbook. Nauplius. Rio Grande 5: 1-225.

Brady, G. S. 1883. Report on the Copepoda collected by H.M.S. Challenger, during the years 1873-76. Report on the Scientific Results of the Voyage of H.M.S. Challenger. Zoology (Jena, Germany) 8: $1-142$.

Brandes, C.-H. 1956. Caligus arcticus n. sp., ein parasitischer Copepode auf Trachypterus arcticus Brünniche. Veroffentlichungen des Institut für Meeresforschung in Bremerhaven 4: 171-181.

Bron, J. E., Sommerville, C. and Rae, G. H. 1993. Aspects of the behavior of copepodid larvae of the salmon louse Lepeophtheirus salmonis (Krøyer, 1837). Pp. 125-140. In: Boxshall, G. A. and Defaye, D. (Ed.). Pathogens of Wild and Farmed Fish: Sea Lice. Ellis Horwood Press, London.

Burmeister, H. 1835. Beschreibung einiger neuen oder weniger bekannten Schmarotzerkrebse, nebst allgemeinen Betrachtungen über die Gruppe, welche sie angehören. Acta Verhandlungen der Leopoldinisch-Carolinischen Akademie der Naturforscher 17: 269-336.

Cherniavsky, V. 1868. [Materials for the comparative zoography of the Pontus-region, which should serve as a basis for the "genealogy of crustaceans"]. Pp. 39-57. In: Trudy Pervogo Saezda Russkih Estestvoispytatelei Sankt-Peterburga, Otdelenie Zoologii [Contributions of the First Meeting of Russian Naturalists, Zoological Section, St. Petersburg]. Imperial Academy of Sciences, St. Petersburg. [In Russian]

Copley, L., Tierney, T. D., Kane, F., Naughton, O., Kennedy, S., O'Donhoe, P., Jackson, D. and McGrath, D. 2005. Sea lice, Lepeophtheirus salmonis and Caligus elongatus, levels on salmon returning to the west coast of Ireland. Journal of the Marine Biological Association of the United Kingdom 85: 87-92.

Costello, M. J., Costello, G. O., Donhoe, N. J., Cohlan, M. O. and Heijdein, Y. V. D. 1998. Planktonic distribution of sea lice larvae Lepeophtheirus salmonis, in Killary Harbour, west coast of Ireland. Journal of the Marine Biological Association of the United Kingdom 78: 853-874.

Cressey, R. 1967. Revision of the family Pandaridae (Copepoda, Caligoida). Proceedings of the United States National Museum 121: $1-133$.

Cressey, R. F. 1969. Caligus hobsoni, a new species of parasitic copepod from California. The Journal of Parasitology 55: 431-434.

Dana, J. D. 1852. Synopsis of characters of parasitic copepods. Proceedings of the American Academy of Arts and Sciences 2: 9-61.

Froese, R. and Pauly, D. 2012. Editors. FishBase. Available at http:// www.fishbase.org (July 2012).

Gnanamuthu, C. P. 1948. Notes on the anatomy and physiology of Caligus savala, n. sp., a parasitic copepod from Madras plankton. Proceedings of the Zoological Society of London 118: 591-606.

Gnanamuthu, C. P. 1950. Three new copepod parasites of the ribbon fish from South India. The Journal of Parasitology 38: 113-119.

Grobler, N. J. 2004. A review of the genus Caligus (Copepoda: Caligidae) from South Africa. Thesis, Department of Zoology and Entomology, University of the Free State. 246 pp.

Gusev, A. V. 1951. Parazitologicheski Sbornik 13: 394-463, Parasitic Copepoda of some marine fishes. [In Russian]

Hayward, C. J., Aiken, H. M. and Nowak, B. F. 2008. An epizootic of Caligus chiastos on farmed southern bluefin tuna Thunnus maccoyii off South Australia. Diseases of Aquatic Organisms 79: 
57-63.

Hayward, C. J., Svane, I., Lachimpadi, S. K., Itoh, N., Bott, N. J. and Nowak, B. F. 2011. Sea lice infections of wild fishes near ranched southern bluefin tuna (Thunnus maccoyii) in South Australia. Aquaculture (Amsterdam, Netherlands) 320: 178-182.

Heegaard, P. 1972. Caliginae and Euryphorinae of the Dana Expedition (Crustacea, Copepoda, Caligidae). Steenstrupia (Copenhagen) 2: 295-317.

Ho, J. S. 1963. On five species of Formosan parasitic copepods belonging to the suborder Caligoida. Crustaceana 5: 81-93.

Ho, J. S. and Bashirullah, A. K. M. 1977. Two species of caligid copepods (Crustacea) parasitic on marine fishes of Venezuela, with discussion of Metacaligus Thomsen, 1949. Journal of Natural History 11: 703-714.

Ho, J. S. and Lin, C. L. 2001. Sea lice (Copepoda, Caligidae) parasitic on carangid fishes of Taiwan. Journal of the Fisheries Society of Taiwan 28: 177-201.

Ho, J. S. and Lin, C. L. 2002. New species of Metacaligus (Caligidae, Copepoda) parasitic on the cutlassfish (Trichiurus lepturus) of Taiwan, with a cladistic analysis of the family Caligidae. Zoological Science 19: 1363-1375.

Ho, J. S. and Lin, C. L. 2004a. Sea Lice of Taiwan (Copepoda: Siphonostomatoida: Caligidae). The Sueichan Press, Keelung, 388 pp.

Ho, J. S. and Lin, C. L. 2004b. Caligus planktonis Pillai (Copepoda: Siphonostomatoida) parasitic on the largescale mullet of Taiwan. Crustaceana 76: 1201-1209.

Ho, J. S. and Sey, O. 1996. Parasitic Copepoda of marine fishes from Kuwait: a preliminary report. Kuwait Journal of Science and Engineering 23: 61-69.

Ho, J. S., Lin, C. L. and Chen, S. N. 2000. Species of Caligus Müller, 1785 (Copepoda: Caligidae) parasitic on marine fishes of Taiwan. Systematic Parasitology 46: 159-179.

Hull, M. Q., Pike, A. W., Mordue, A. J. and Rae, G. H. 1998. Patterns of pair formation and mating in an ectoparasitic caligid copepod $\mathrm{Le}$ peophtheirus salmonis (Krøyer, 1837): implications for its sensory and mating biology. Philosophical Transactions of the Royal Society of London 353: 753-764.

Huys, R. and Boxshall, G. A. 1991. Copepod Evolution. The Ray Society, London, $468 \mathrm{pp}$.

Hwa, T.-K. 1965. Studies on the life history of a fish-louse (Caligus orientalis Gusev). Acta Zoologica Sinica 17: 48-58. [In Chinese]

Izawa, K. and Choi, K. H. 2000. Redescription of Caligus latigenitalis (Shiino, 1954) (Copepoda, Siphonostomatoida, Caligidae), parasitic on Japanese black seabream, Acanthopagrus schlegelii (Bleeker, 1854). Crustaceana 73: 995-1005.

Kabata, Z. 1979. Parasitic Copepoda of British Fishes. The Ray Society, London. 468-pp.

Kim, I. H. 1998. Cirripedia, Symbiotic Copepoda, Pycnogonida. Illustrated Encyclopedia of Fauna and Flora of Korea. Vol. 38. Ministry of Education, Korea, Seoul, 1038 pp. [In Korean]

Kirtisinghe, P. 1964. A review of the parasitic copepods of fish recorded from Ceylon, with description of additional forms. Bulletin of Fisheries Research Station. Ceylon. 17: 45-132.

Li, M. 1984. Parasites of the mullets Mugil cephalus (Linnaeus) and Liza haemotocheilia (Temminck et Schlegel) in the areas of Bohai Gulf. II. Pengalai area. Acta Zoologica Sinica 30: 231-241. [In Chinese]

Lin, C. L. and Ho, J. S. 1998a. On a species of Copepoda, Caligus orientalis Gusev, 1951 (Crustacea: Copepoda: Caligidae) parasitic on the fishes cultured in saltwater. Journal of the Fisheries Society of Taiwan 25: 199-208.

Lin, C. L. and Ho, J. S. 1998b. Identification of sea lice parasitic on fishes cultured in Taiwan. Journal of the Chiayi Institute of Technology 59: 93-107.

Lin, C. L. and Ho, J. S. 2007. Six species of sea lice (Copepoda,
Caligidae) new to Taiwan. Journal of the Fisheries Society of Taiwan 34: 41-67.

Lin, C. L., Ho, J. S. and Chen, S. N. 1994. Two species of Caligus (Copepoda: Caligidae) parasitic on black sea bream (Acanthopagrus schlegeli) cultured in Taiwan. Fish Pathology 29: 253-264.

Margolis, L. and Parker, R. R. 1966. Caligus japonicus Gusev in Isakovakeo, 1952, a synonym of Caligus orientalis Gusev, 1951 (Copepoda, Caligidae). Crustaceana 10: 311.

Markevich, A. P. 1956. [Parasitic Copepods on the Fishes of USSR]. Paraziticheskie Vesolonogie Ryb USSR. Izdatel'stvo Akademii Nauk Ukrainskoi SSR, Kiev, 259 pp. [In Russian]

Matumoto, T. 1980. Caligus orientalis parasitic on cultured carp. Fish Pathology 14: 143-144.

Milne-Edwards, H. 1840. Orde des Copepodes. In Histoire naturelle des Crustacés, comprenant l'anatomie, la physiologie et la classification de ces animaux 3: 411-529.

Montú, M. 1982. Alguns copépodos parasites de peixes do sul do Brasil. Arquivos de Biologia e Tecnologia 25: 329-339.

Nagasawa, 1994. Parasitic Copepoda and Branchiura of freshwater fishes of Hokkaido. Scientific Reports of the Hokkaido Fish Hatchery 48: 83-85.

Nagasawa, K. 2004. Sea lice, Lepeophtheirus salmonis and Caligus orientalis (Copepoda: Caligidae), of wild and farmed fish in sea and brackish waters of Japan and adjacent regions: a review. Zoological Studies 43: 173-178.

Nagasawa, K., Uyeno, D. and Tang, D. 2010. A checklist of copepods of the genus Caligus (Siphonostomatoida, Caligidae) from fishes in Japanese waters. Bulletin of Biogeographical Society of Japan 65: 103-122.

Ohtsuka, S., Ho, J. S. and Nagasawa, K. 2004. Ergasilid copepods (Poecilostomatoida) in plankton samples from Hokkaido, Japan, with reconsideration of the taxonomic status of Limnoncaea Kokubo, 1914. Journal of Natural History 38: 471-498.

Penston, M. J., McKibben, M. A., Hay, D. W. and Gillibrand, P. A. 2004. Observations on open water densities of sea lice larvae in Loch Shieldaig, western Scotland. Aquaculture and Research 35: 793805.

Pillai, N. K. 1963. Copepods parasitic on South Indian fishes and family Caligidae. Journal of the Marine Biological Association of India 5: 68-96.

Pillai, N. K. 1966. Notes on copepod parasitic on South Indian marine fishes. Journal of the Marine Biological Association of India 8: 123-140.

Pillai, N. K. 1985. The Fauna of India. Copepod Parasites of Marine Fishes. Zoological Survey of India, Calcutta, 900-pp.

Pillai, N. K. and Natarajan, R. 1977. Copepods parasitic on fishes of the Kerala coast. Aquatic Biology 19: 19-43.

Rangnekar, M. P. 1959. Parasitic copepods from fishes of the western coast of India with description of one new and redescription of four known species. Journal of the University of Bombay 28: 4358.

Rosenberg, A. A. 2008. Aquaculture: the price of lice. Nature 451: 2324.

Shen, C. J. 1957. Parasitic copepods from fishes of China, IV. Caligoida. Caligidae (1). Acta Zoologica Sinica 9: 351-377 [In Chinese with English summary]

Shen, C. J. and Li, H. L. 1959. Parasitic copepods from fishes of China, IV. Caligoida. Caligidae (3). Acta Zoologica Sinica 11: 12-23 [In Chinese with English summary]

Shiino, S. M. 1954a. On the new copepod, Caligus calotomi n. sp., parasitic on the fish, Calotomus japonicus $(\mathrm{C} \& \mathrm{~V})$. Bulletin of the Japanese Society of Scientific Fisheries 20: 16-20.

Shiino, S. M. 1954b. Copepods parasitic on Japanese fishes 5. Five species of the family Pandaridae. Report of the Faculty of Fisheries. 
Prefectural University of Mie 1: 291-332.

Shiino, S. M. 1957. Copepods parasitic on Japanese fishes 13. Parasitic copepods collected off Kessenuma, Miyagi Prefecture. Report of the Faculty of Fisheries. Prefectural University of Mie 2: 359-375.

Shiino, S. M. 1959a. Ostpazifische parasitischen Copepoden. Report of the Faculty of Fisheries. Prefectural University of Mie 3: 267-333.

Shiino, S. M. 1959b. Sammlung der parasitischen Copepoden in der Präfekturuniversität von Mie. Report of the Faculty of Fisheries. Prefectural University of Mie 3: 334-374.

Shiino, S. M. 1960. Copepods parasitic on the fishes collected on the coast of Province Shima, Japan. Report of the Faculty of Fisheries. Prefectural University of Mie 3: 471-500.

Shiino, S. M. 1963. Note on Lepeophtheirus semicossyphi Yamaguti (Copepoda: Caligoida). Publications of the Seto Marine Biological Laboratory 11: 409-414.

Suárez-Morales, E., Kim, I. H. and Salgado, I. L. 1998. An illustrated record and range extension of Caligus chelifer Wilson (Copepoda: Siphonostomatoida) in the Gulf of Mexico. Gulf Research Reports 10: 57-60.

Suárez-Morales, E., Kim, I. H. and Escamilla, J. B. 2003. Illustrated record and complementary description of Caligus rufimaculatus Wilson (Copepoda: Siphonostomatoida) from Mexico. Caribbean Journal of Science 39: 151-154.

Suárez-Morales, E., Camisotti, H. and Martín, A. 2012. A new species of Caligus (Copepoda, Siphonostomatoida) from the plankton of the Caribbean coast of Venezuela with a key to species. Zookeys 201: 59-71.

Suzumoto, H. 1974. On a caligid parasite found on injured crusian carp, Carassius auratus in Lake Shinji. Fish Pathology 8: 23-27.

Tang, D. and Newbound, D. R. 2004. A new species of copepod (Siphonostomatoida: Caligidae) parasitic on the tiger shark Galeocerdo cuvier (Péron \& Lesueur) from Western Australian waters. Systematic Parasitology 58: 69-80.

Thomsen, R. 1949. Copepods parasites de los peces marinos del Uruguay. Comunicaciones Zoologicas del Museo de Historia Natural de Montevideo 3: 1-41.

Thorell, T. 1859. Bidrag till Kännedomen om Krustaceer, som lefva i Arter af Slägtet Ascidia L. Kungliga Vetenskapsakademien Handlingar 3: 1-84.

Todd, C. D., Laverack, M. S. and Boxshall, G. A. 1996. Coastal Marine Zooplankton: A Practical Manual for Students. 2nd Edition. Cambridge University Press, Cambridge. 106 pp.

Urawa, S. and Kato, T. 1991. Heavy infections of Caligus orientalis Gussev (Copepoda: Caligidae) on caged rainbow trout Oncorhynchus mykiss in brackish water. Fish Pathology 26: 161-162.

Urawa, S., Muroga, K. and Izawa, K. 1979. Caligus orientalis Gussev (Copepoda) parasitic on akame (Liza akame). Fish Pathology 13: 139-146.

Venmathi Maran, B. A. and Ohtsuka, S. 2008. Descriptions of caligiform copepods in plankton samples collected from East Asia: Accidental occurrences or a new mode of life cycle? Plankton \& Benthos Research 3: 202-215.

Venmathi Maran, B. A., Leong, T. S., Ohtsuka, S. and Nagasawa, K. 2009. Records of Caligus (Crustacea: Copepoda: Caligidae) from marine fish cultured in floating cages in Malaysia with a redescription of male Caligus longipedis Bassett-Smith, 1898. Zoological Studies 48: 797-807.

Venmathi Maran, B. A., Ohtsuka, S. and Jitchum, P. 2012a. Occurrences of caligid copepods (Crustacea) in plankton samples collected from Japan and Thailand, with the description of a new species. Species Diversity 17: 87-95.

Venmathi Maran, B. A., Oh, S.-Y., Soh, H. Y., Choi, H. J. and Myoung, J.-G. 2012b. Caligus sclerotinosus (Copepoda: Caligidae), a serious pest of cultured red seabream Pagrus major (Sparidae) in Korea. Veterinary Parasitology 188: 355-361.

Wilson, C. B. 1907. North American parasitic copepods belonging to the family Caligidae, 3 and 4: A revision of the Pandarinae and the Cecropinae. Proceedings of the United States National Museum 33: 323-490.

Wilson, C. B. 1914. The male of Pandarus satyrus Dana. Science Bulletin. Museum of the Brooklyn Institute of Arts and Sciences 2: 71-72.

Yamaguti, S. 1936. Parasitic Copepods from Fishes of Japan. Part 1. Cyclopoida, I. Published by the autho, Kyoto, 8 pp.

Yamaguti, S. 1939. Parasitic Copepods from Fishes of Japan. Part 5. Caligoida. III. Published by the author, Kyoto, Pp. 443-487.

Yamaguti, S. 1963. Parasitic Copepoda and Branchiura of Fishes. Interscience Publishers, New York, 1104 pp.

Yin, W. Y. 1962. Parasitic copepods and Branchiura of freshwater fishes from northeast China and inner Mongolia. Acta Hydrobiologica Sinica 1: 31-46, In Chinese with English summary.

Yoda, M. 1973. An observation of a surface parasite, Caligus laticorpus, on cultured mullet (Liza haemotocheilia). Fish Pathology 8: 98-101.

Yü, S. C. 1933. Chinese parasitic copepods collected by H.W. Wu, with descriptions of new genera and species. Bulletin of the Fan Memorial Institute of Biology 4: 117-138, In Chinese with English summary. 